\title{
المقاصد عند الحنابلة
}

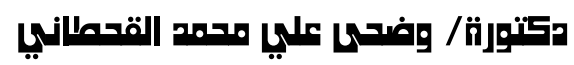

الأستاذ المساعد بقسم الار اسات الإسلامية

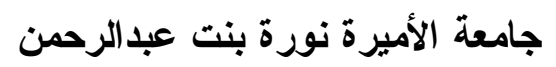

\section{ملخص البحث}

هذا البحث عنوانه: 》 المقاصد عند الحنابلةه، وظاهر من خلال العنوان بنــاء

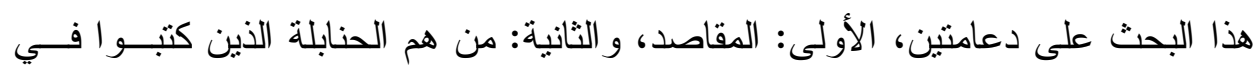
المقاصد.

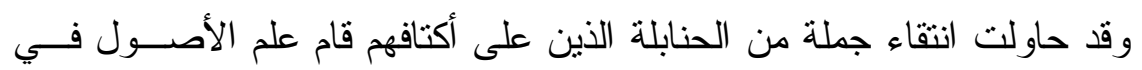

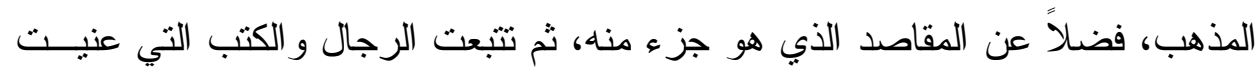

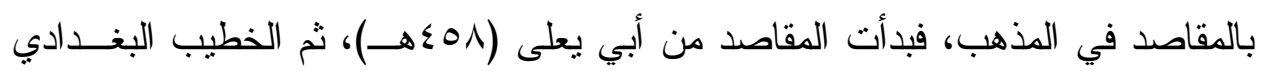

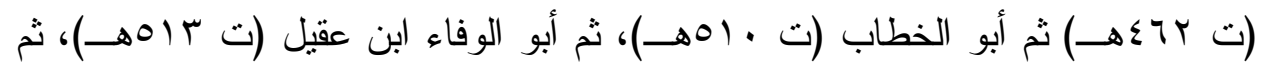

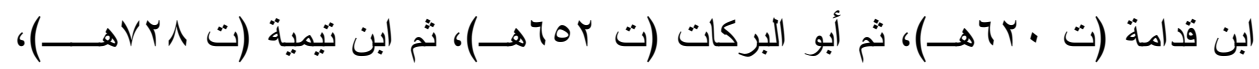

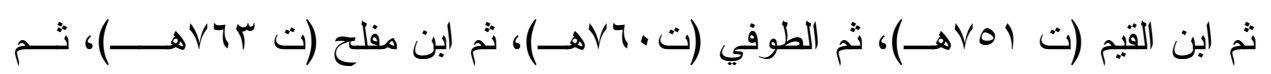

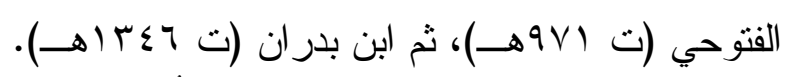

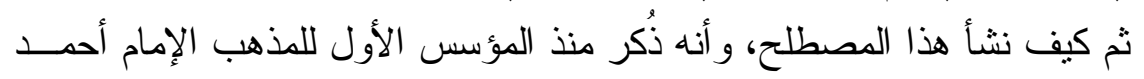

بن حنبل، لكن كان على شكل إثنار ات مقاصدية تبينت من خلال تتبع فتاويه ، ثم علماء

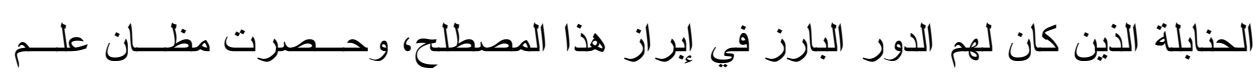

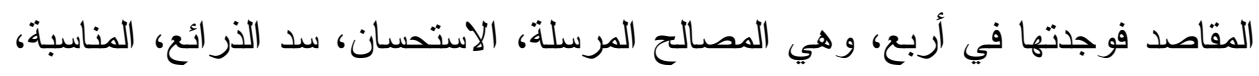
وذكرت النطبيقات الفقهية للاستدلال على ما ذكر في البحث. 


\section{Research Summary}

This research is entitled: "The development of thought Almkasadi at the Hanbalis", and it clear through the title: building of this research on two pillars: the first: the evolution of thought Almqasdi, and the second: Who Hanbala who developed? and what kind of development.

It has tried to chose a group of Hanbalis who carrey on their shoulders the fundamentalist ideology in the mathhab, as well as the Makassed thought which is part of it, and then traced the men and books that were concerned with the principles of figh in the mathhab.from Ibn

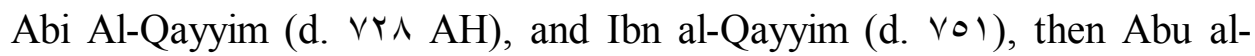
Khattab (01•) , Al-Tufi (Vฯ. AH), Ibn Mufleh (Vฯr AH), Al-Fotouhi ( $9 \vee 1 \mathrm{AH})$ and Ibn Badran ( 1 \% $\leqslant 7 \mathrm{AH}$ ).

Then how the term develop, and that it was mentioned since the first founder of the mathhab of Imam Ahmad ibn Hanbal, but was in the form of causative signs were identified by tracking the fatwa, then the historical survey, which is represented in the trace of the term only regardless of who he is and what mathhab, The scholars of Hanbalis, who had a prominent role in highlighting this term, namely Ibn Taymiyyah, Ibn al-Qayyim, al-Tufi, and al-Fatuhhi, and restricted the meanings of the Makassed vocabulary, which was meant by the purposes and found them in four, as well as the sentiments, According to the research. 
مقدمة

إن الحمد لله، نحمده ونستعينه، ونستغفره، ونتوب إليه، ونعوذ بالله من شــرور

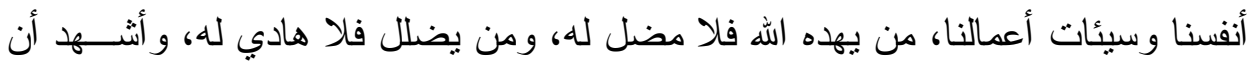

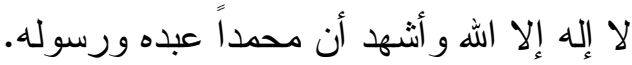
أما بعد:

إن الثريعة الإسلامية وضعت لمصالح العباد في العاجل و الاجل معاً،وهذا مـــا

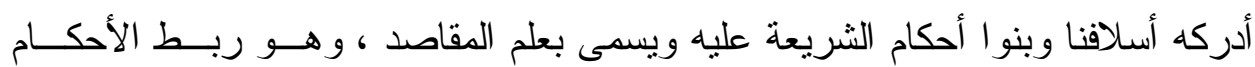

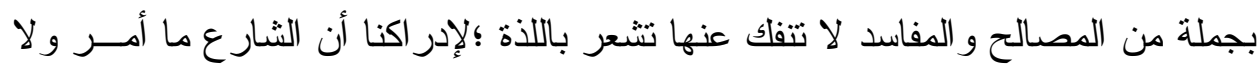

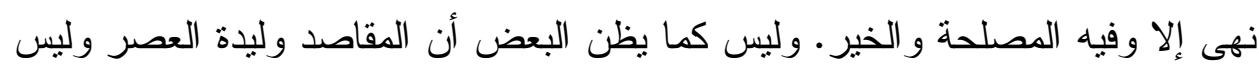

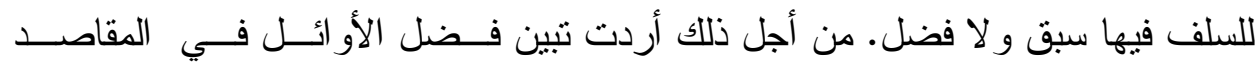

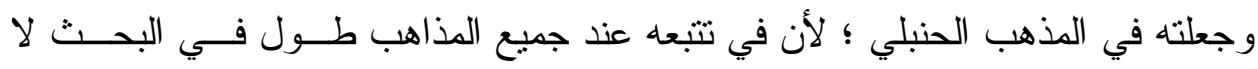

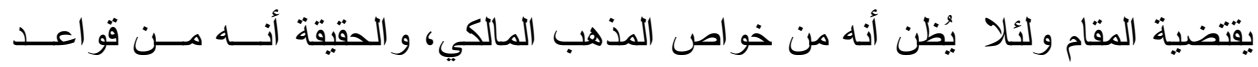
الثريعة وليس مذهباً. أسباب اختيار الموضوع:

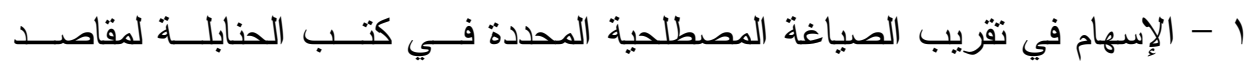

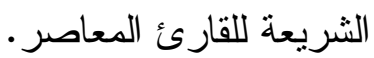
r - إظهار دور الحنابلة في المقاصد ، بالرغم أنه لم يكن لهم كتاب مستقل فيها. منهج البحث: الطهار حاولت صياغة الموضوع بجزئياته المختلفة وفـق المــنهج التــاريخي الوصــفي

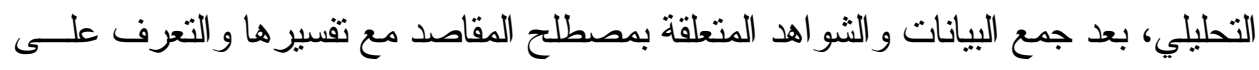
مكانها في كتب الحنابلة ضمن الإطار المعرفي الأصولي. أهمية البحث: مانية

1 - توضيح مصطلح "علم المقاصد" وربطها بمباحث الأصول المذكورة في البحث. r - نمنل هذه الدر اسة ما أصله علماء الحنابلة في علم المقاصد. خطة البحث: تمهيد، وثلاثة مباحث، وخاتمة. المبحث الأول: تعريف المقاصد و استعماله عند العلماء، وفيه مطلبان: المطلب الأول: تعريف المقاصد. 


$$
\text { المطلب الثاني: استعمال المقاصد عند العلماء. }
$$

المبحث الثاني: مظان علم المقاصد عند الحنابلة، وفيه أربعة مطالب:

$$
\text { المطلب الأول: المناسبة. }
$$

المطلب الثاني: المصلحة المرسلة.

$$
\text { المطلب المطلب الثالث: سد الذرائع. }
$$

المبحث الثالث: التطبيقات المقاصدية عند الحنابلة، وفيه مطلبان:

$$
\text { المطلب الأول: النطبيقات في العبادات. }
$$

المطلب الثاني: النطبيقات في المعاملات. 


\section{التمهيد}

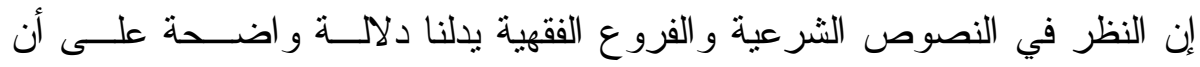

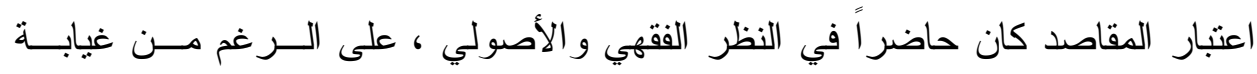

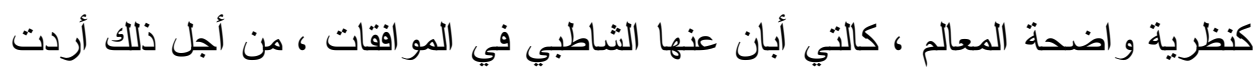

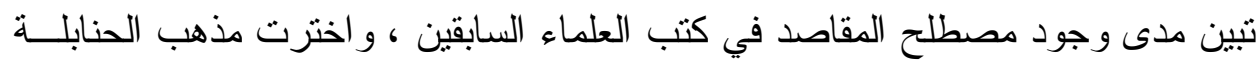

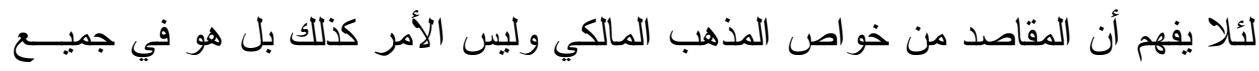

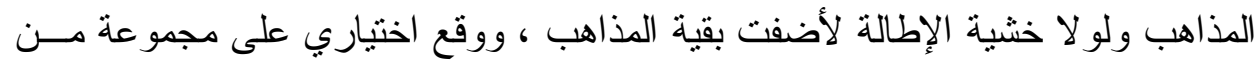

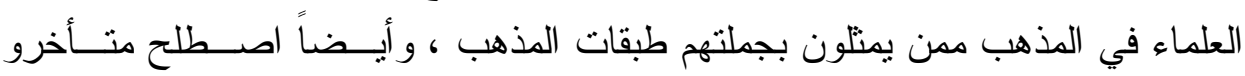

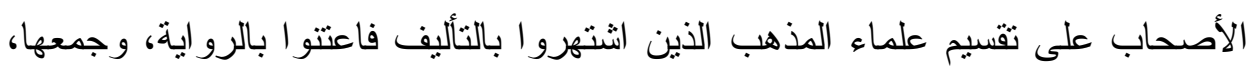

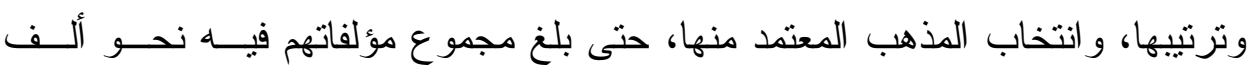

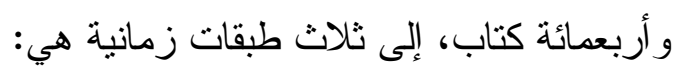

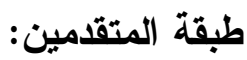
تبدأ هذه الطبقة في منتصف القرن الثالث من تلامذة الإمام أحمد المتــوفى بمـائتين

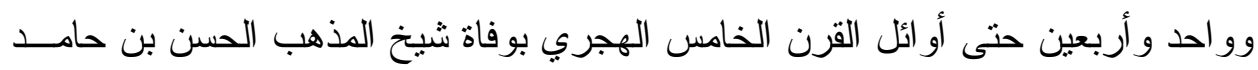

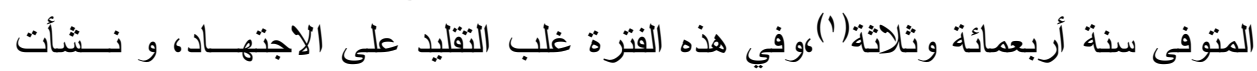

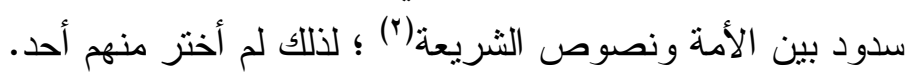
طبقة المتوسطين:

هذه الطبقة هي طبقة تحرير المذهب، وتبدأ من أو ائل القرن الخامس حتى منتــصف

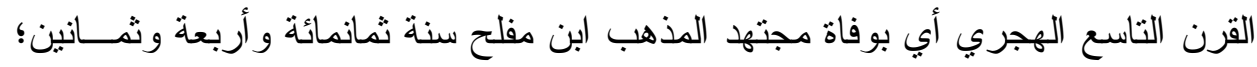

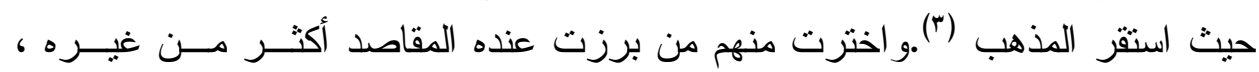

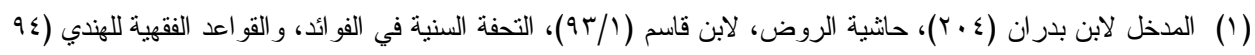

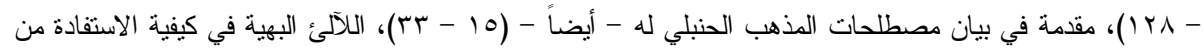

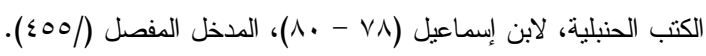

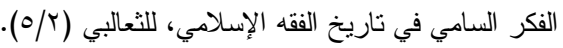

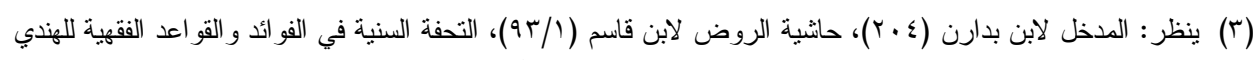

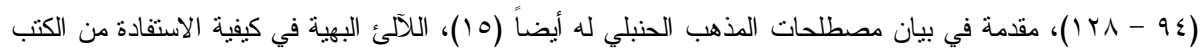

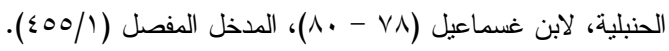


القاضي أبو يعلى، وأبو الخطاب، و أبو الوفاء ابن عقيل، و الخطيب البغــدادي ، وابـن

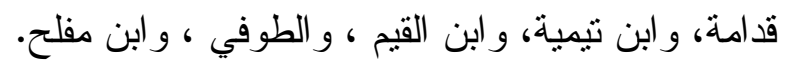

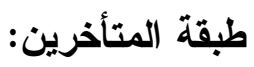
تبدأ هذه الطبقة من منتصف القرن التاسع من رأس المتأخرين و إمــام المــذهب الإمــام

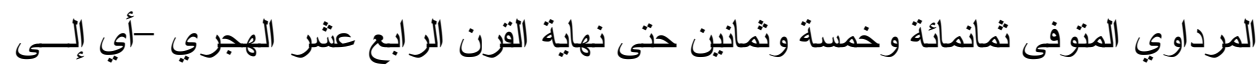
يومنا و لا حد لنهايتها-(')، واخترت منهم الفتوحي، وخئه وابن بدران.

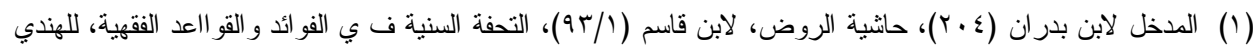

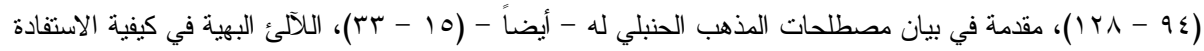

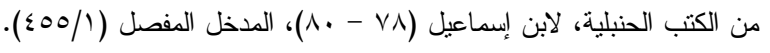




\section{المبحث الأول}

المطلب الأول: تعريف المقاصد:

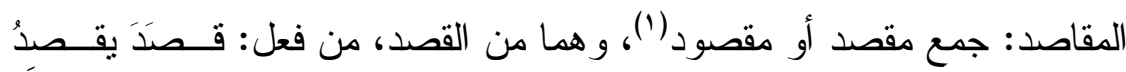

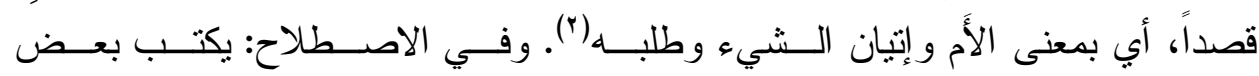

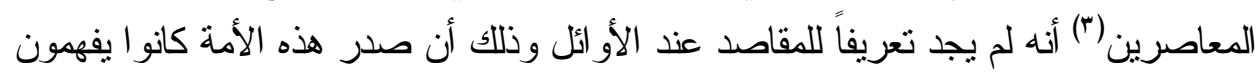

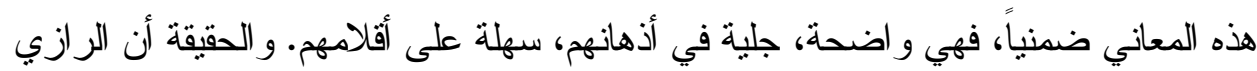

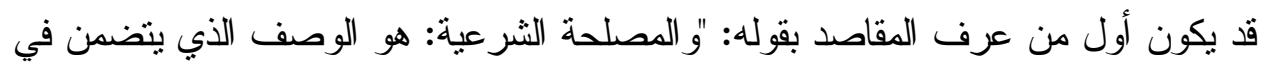

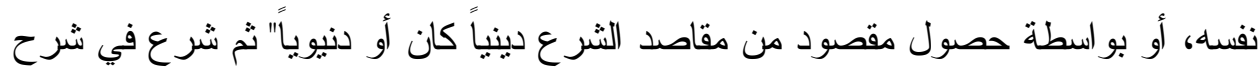

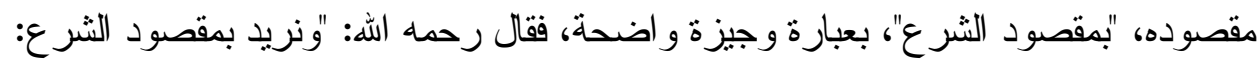

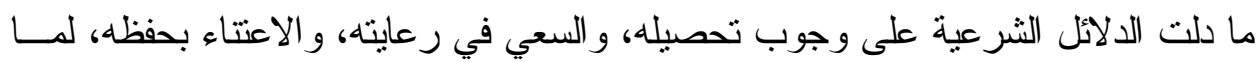

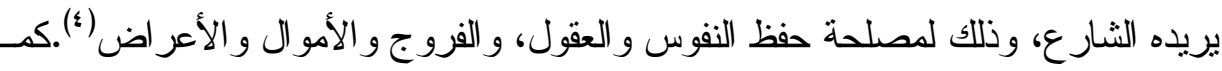

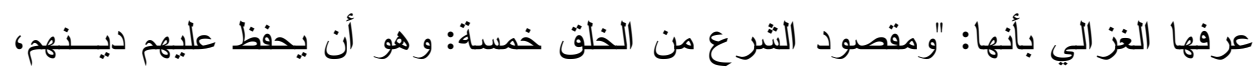

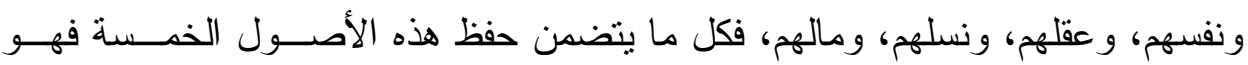

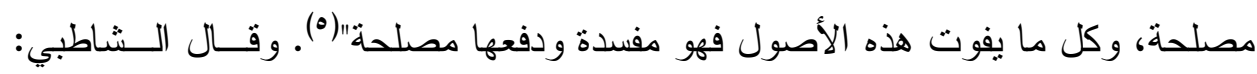

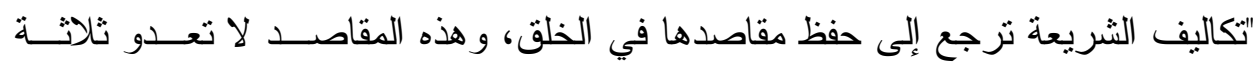

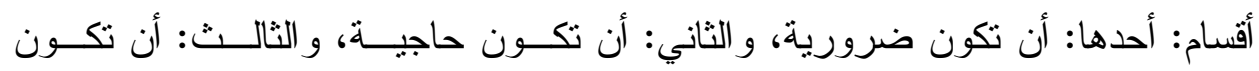

تحسينية"(").

المطلب الثاني: استعمال المقاصد عند العلماء

و السؤال الذي يطرحه هذا المطلب من العلماء الذين بدأوا الحديث في المقاصد؟

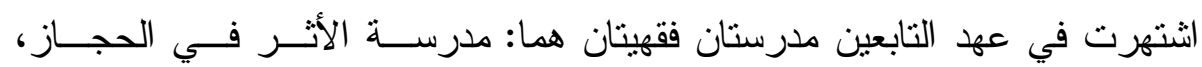

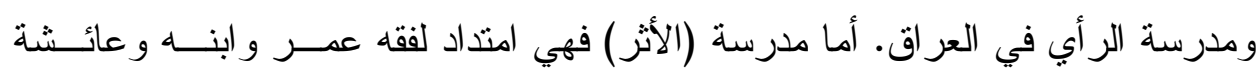

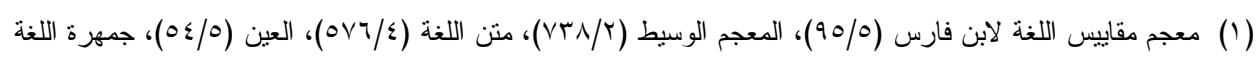

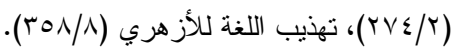
(Y) المر اجع السابقة.

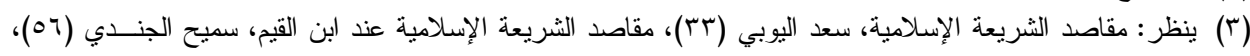

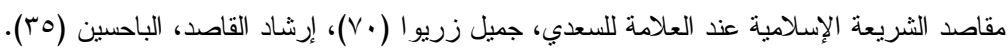

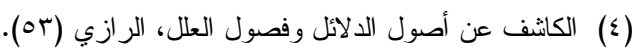

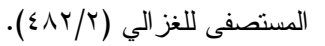
المو افقات للثاطبي (IV/T). 


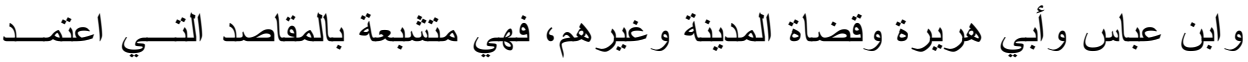

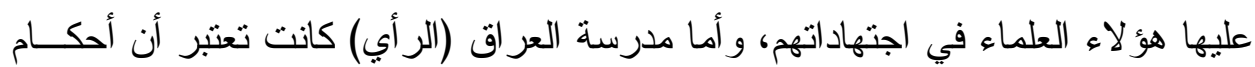

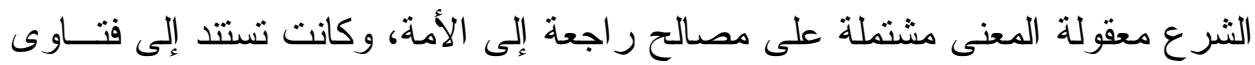

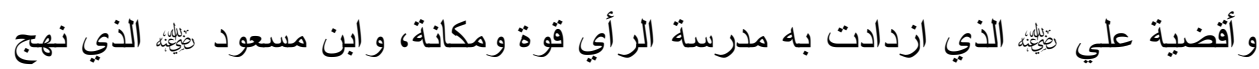

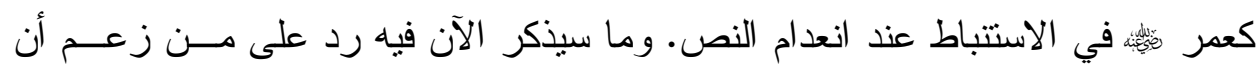

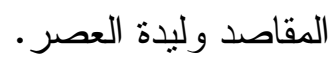

1 - الإمام الثافعي، كان من أو ائل من كتب في أصول الفقه و علم المقاصد حيث تكلـــ

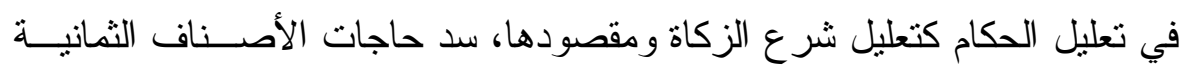

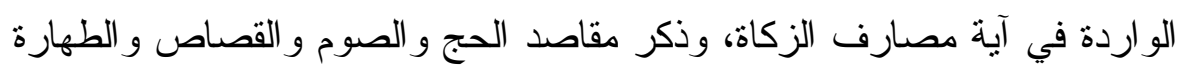
و غير ذلك (')

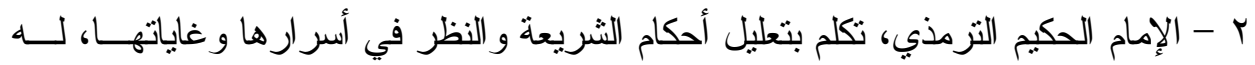

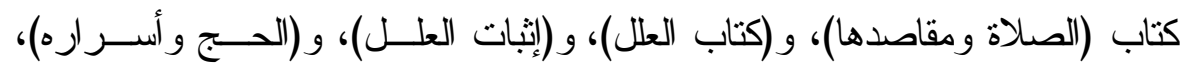

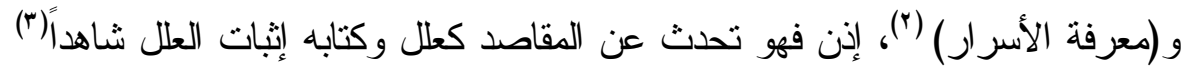

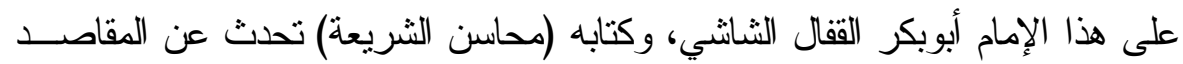

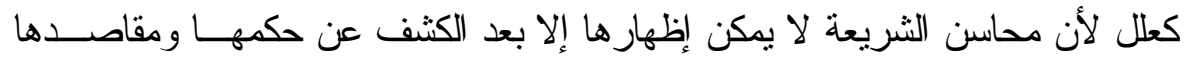

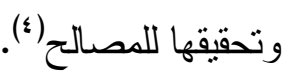

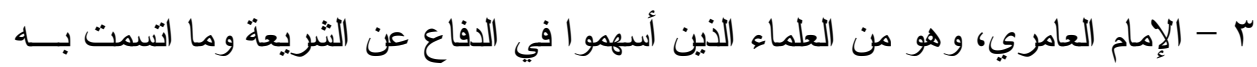

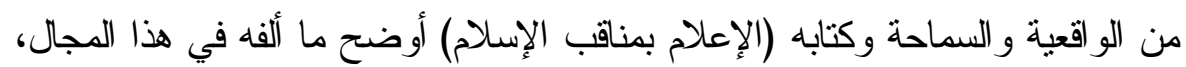

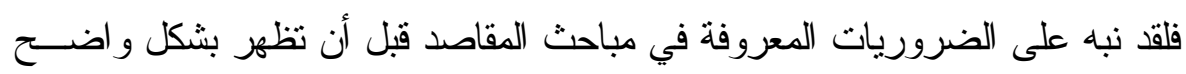

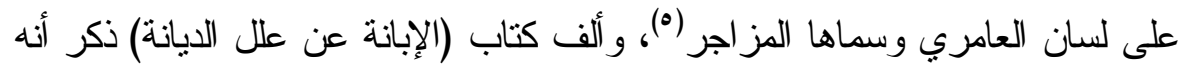

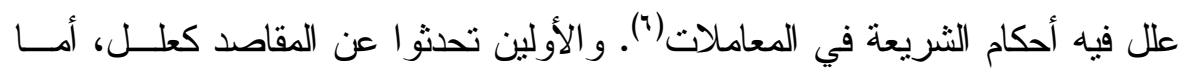
العامري فهو أول من تحدث عن الكليات الخمس. 


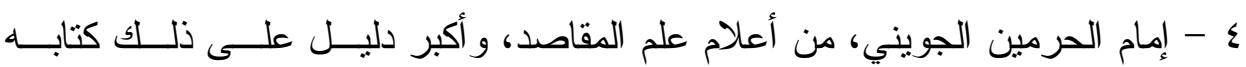

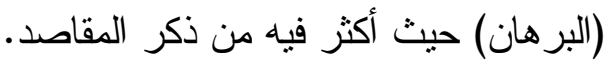

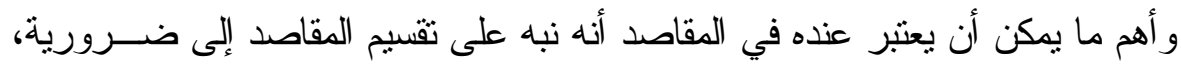

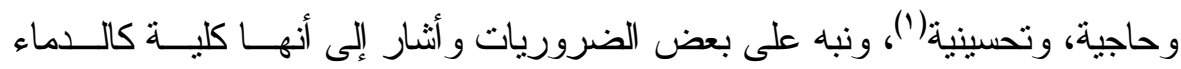

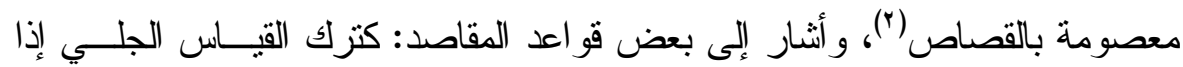

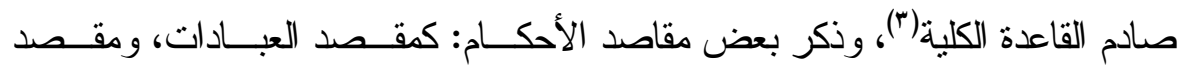

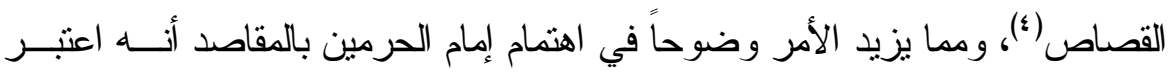
معرفتها من البصيرة في الدين (ه).

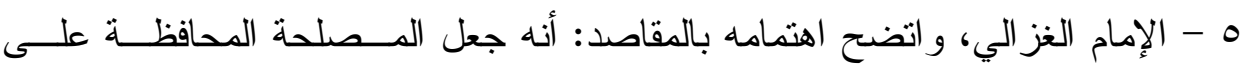
مقصود الثرع(")، وقسم المصلحة إلى ضروريات، وحاجيات، وتحسينيات، وذكر

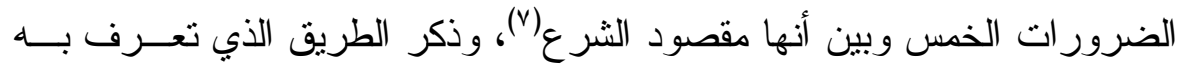

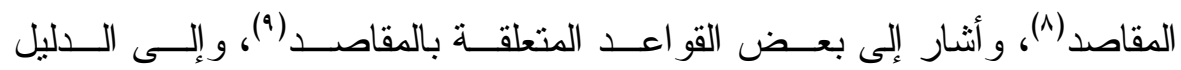

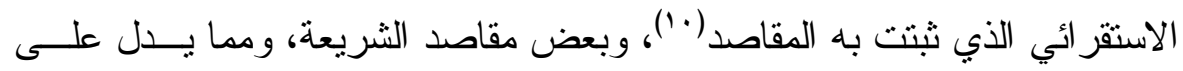

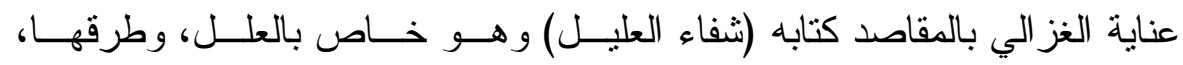
وقو ادحها وفي كتابه (المستصفى) تتضح عند الغزالي المقاصد بشكل جلي أكتــر

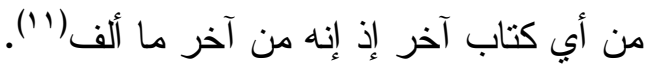

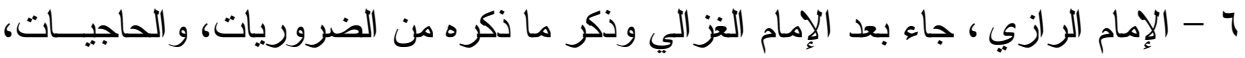

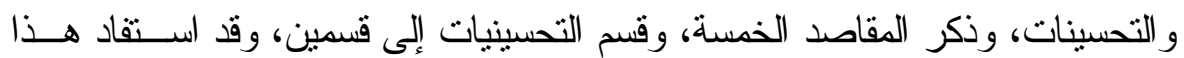

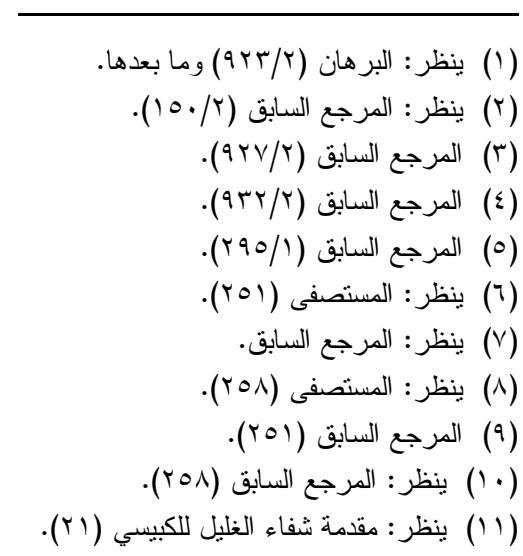


التقبيم من الإمام الجويني، وأيضاً أدخل المقاصد في باب التزجيح بين الأقيسة بعد أن

كانت تنكر في باب المناسبة و المصالح المرسلة فقط الجمام ول.

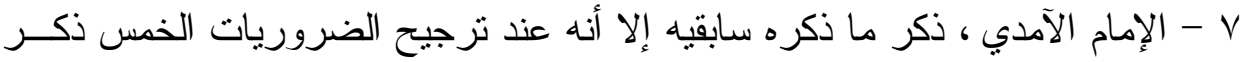

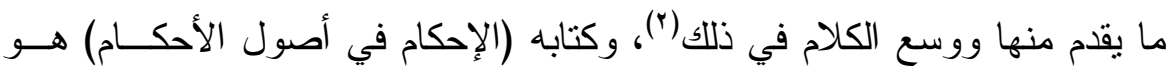

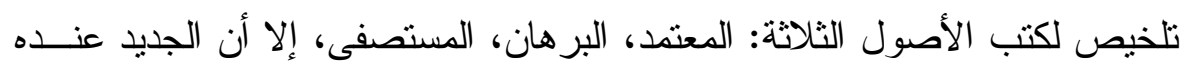

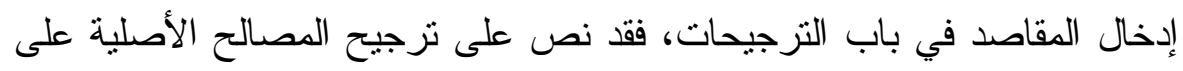
مكملاتها، وترجيح مكملات الضروريات على مكملات الحاجيات(بّات.

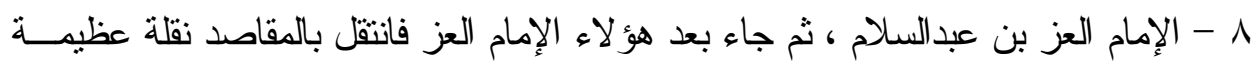

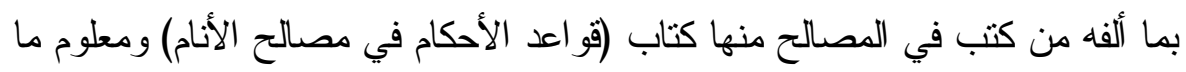

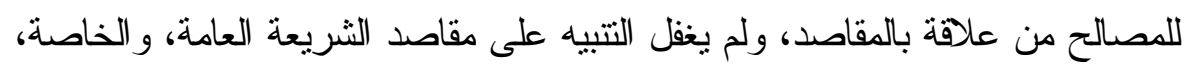

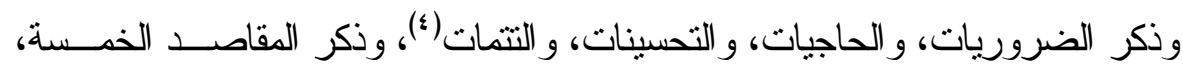
وذكر التزجيح بين الضروريات وما بتزتب على التفاوت بينها، وذكر المقاصد الجزئية

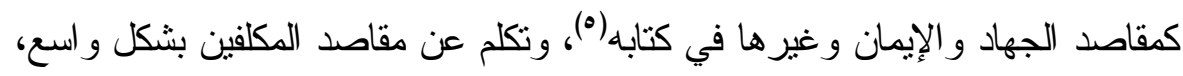

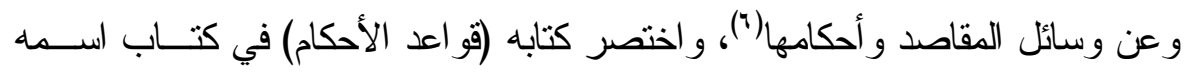

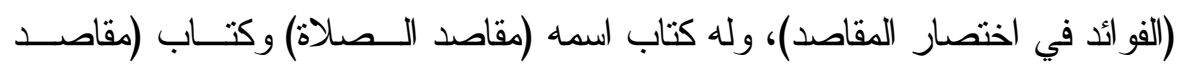

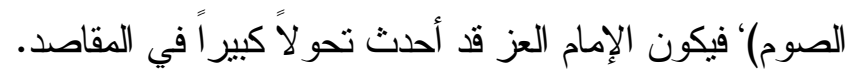

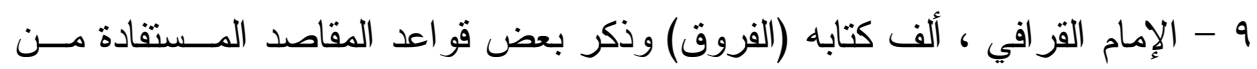

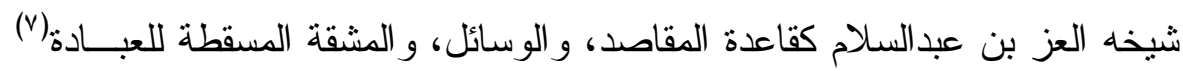

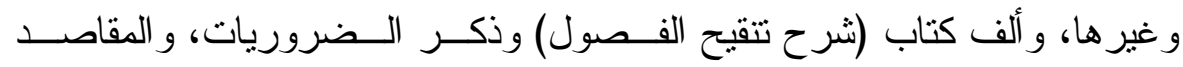

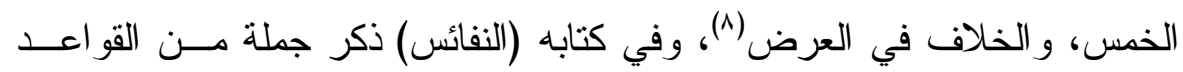

$$
\begin{aligned}
& \text { (1) ينظر: المحصول (Y/Y) بآT). }
\end{aligned}
$$

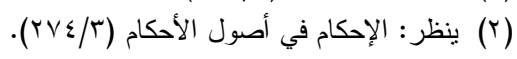

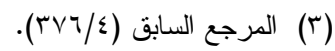

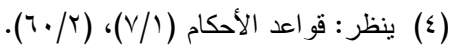

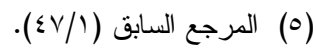

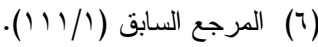

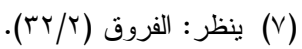

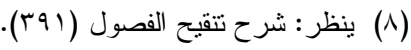


الخاصـة بالمقاصد (')، منل أن الكليات الخمس لا يـــخلها النـسخ، ومــن اســتقر أ مؤلفاته علم أنه من مؤسسي علم المقاصد.

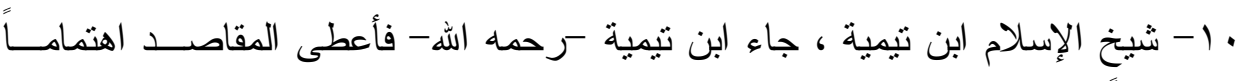

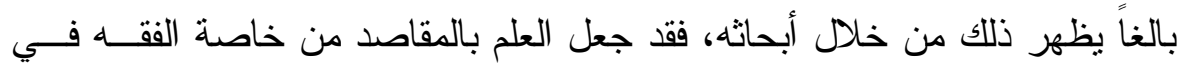

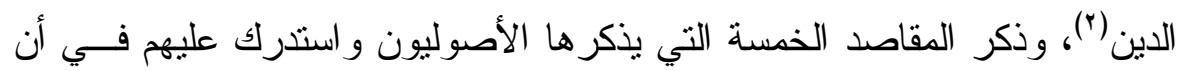

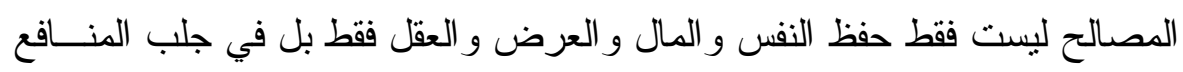

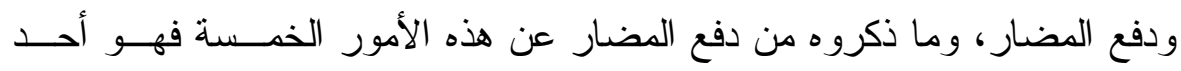

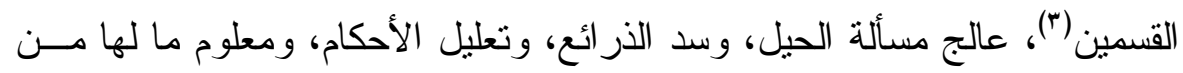

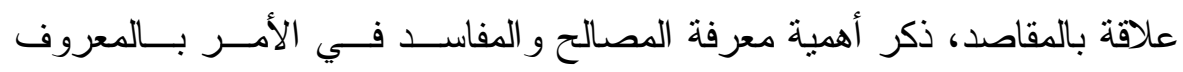

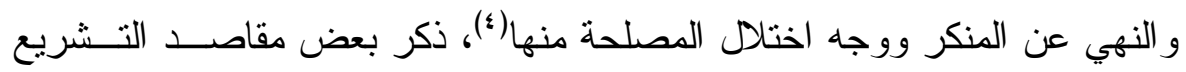
كمقصد الولاية و الجهاد (•). 11 - الإمام ابن القيم الجوزية ، اهتم بإثبات مقاصد الثريعة، وتعليل الأحكــام، وبيــان

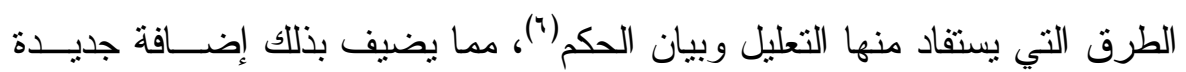

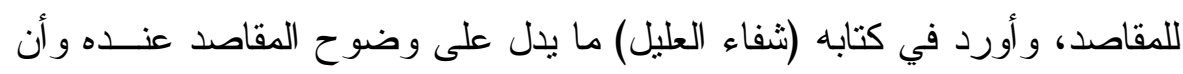

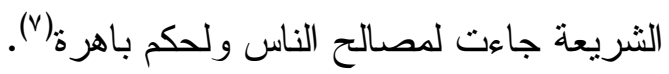

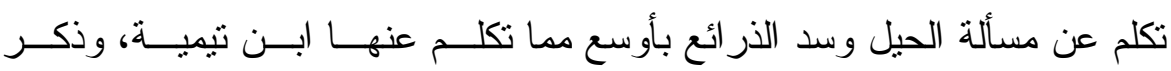

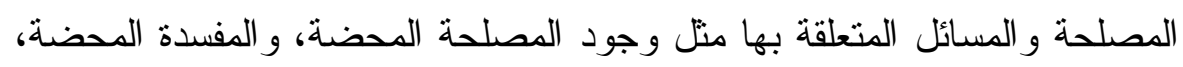

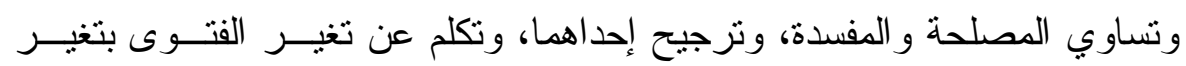

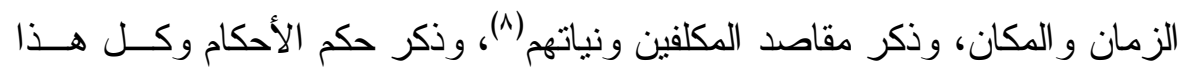
منتور في كتبه منت (ز اد المعاد) و وشفاء العليل) و غير ها.

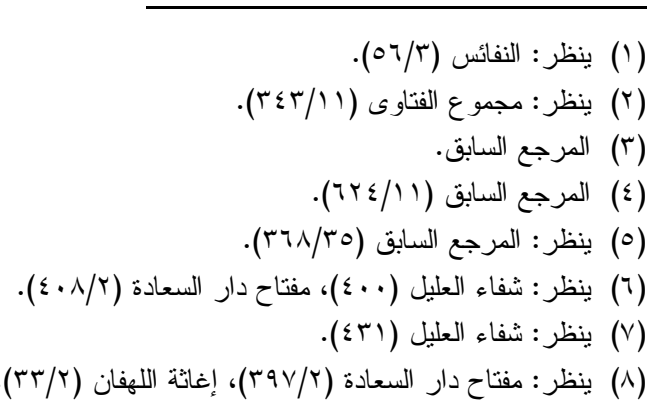


r ا- الإمام الطبري ، توسع في كلامه عن المصلحة عنـــ شــرحه للحــديث الثـاني

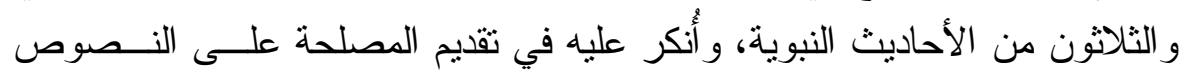

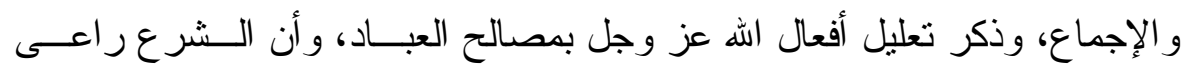

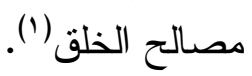
با - الإمام المقري ، جاء وسطاً بين أستاذيه ابن القيم و القر افي وبين تلميذه الـشاطبي

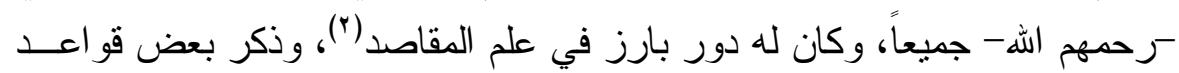

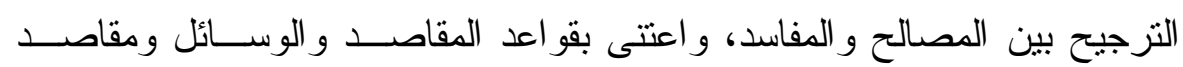
المكلفين (").

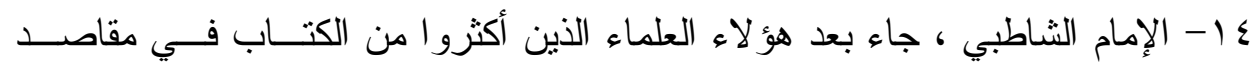

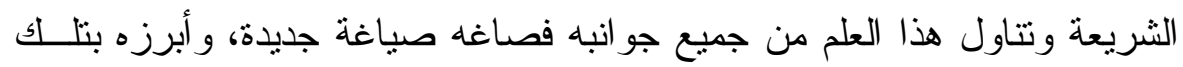

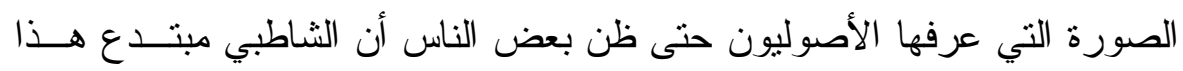

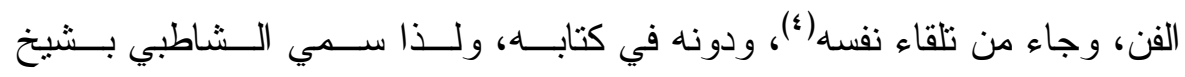

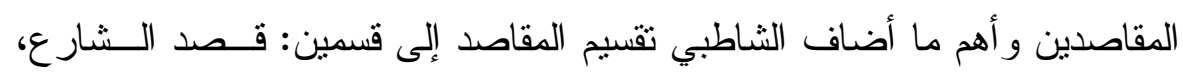
وقصد المكلف(ه)، وإضافة بعض المباحث المهمة في المقاصد منل وضع الثريعة

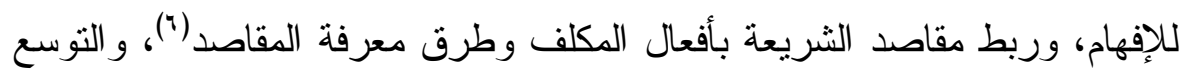
في التفريع على مقاصد الثريعة، وربط المقاصد بكثثر من المسائل الأصولية.

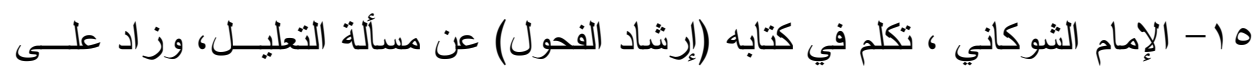
الضرورات الخمس العرض(v)، تكلم عن المصالح، و أنكر الحيل واستخدامها مـنـن قبل الفقهاء. 7 ا - الإمام ابن عاثور ، ألف كتابه (مقاصد الثريعة) بلغة سهلة لا تعقيد فيها، وذكر مقاصد

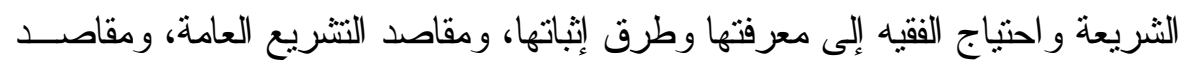

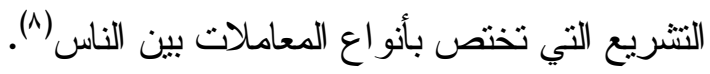

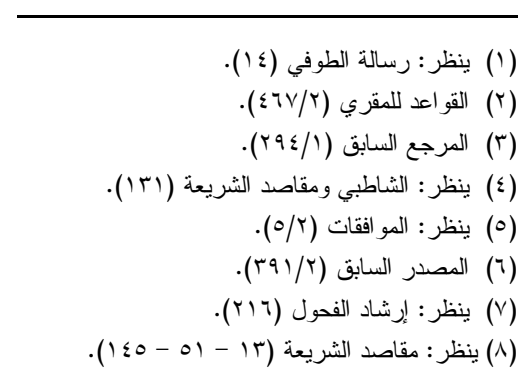


IV - الإمام علال الفاسي ، ألف كتابه (مقاصد الثريعة ومكارمها).

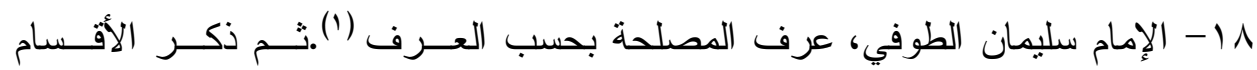

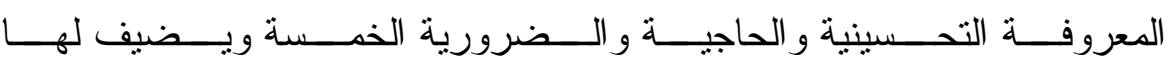

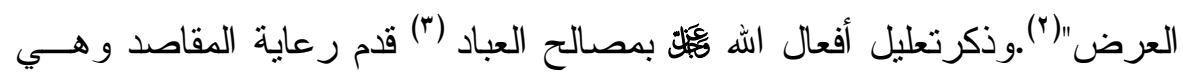

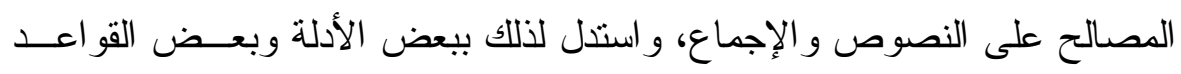

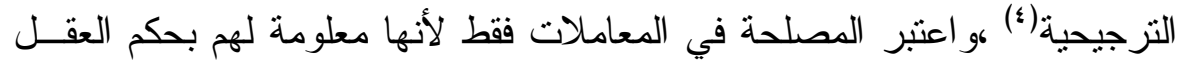
و العادة:(0).

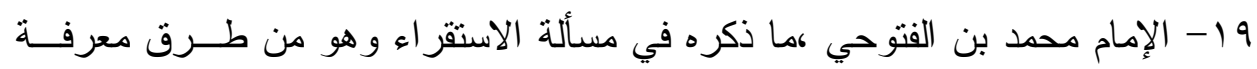

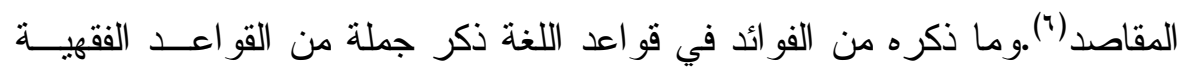

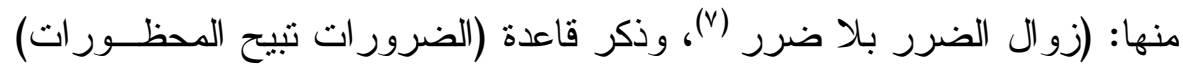

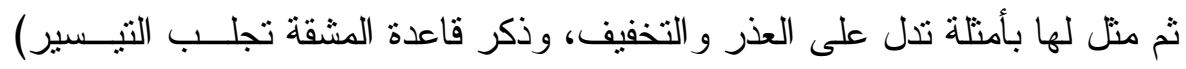

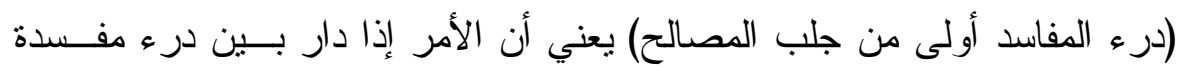

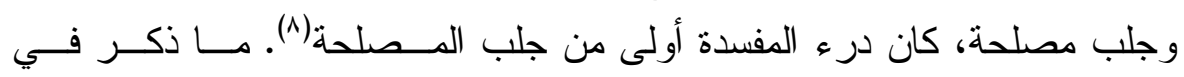

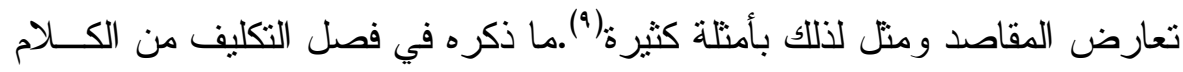
عن المقاصد و التكليف بما بطاق (·").

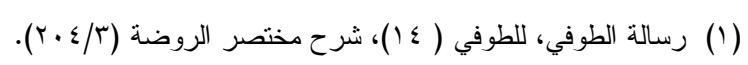

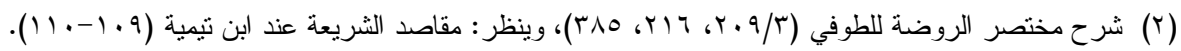

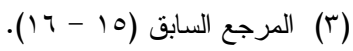

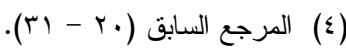

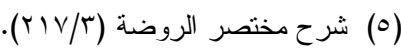

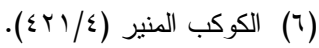

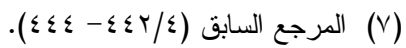

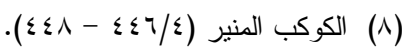

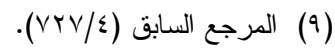

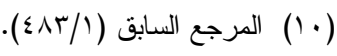




\section{المبحث الثاني \\ مظان علم المقاصد عند الحنابلة}

من الألفاظ ذات الصلة بالمقاصد: الحكمة، المعنى، العلة، المناسبة، المصلحة (1)، أمســا

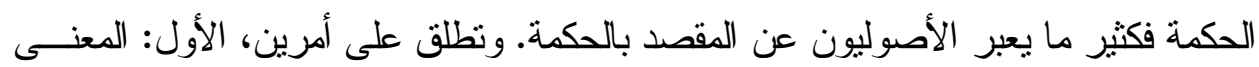

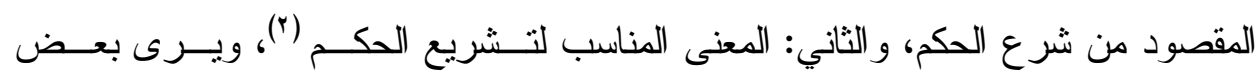

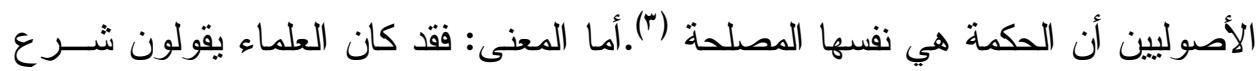

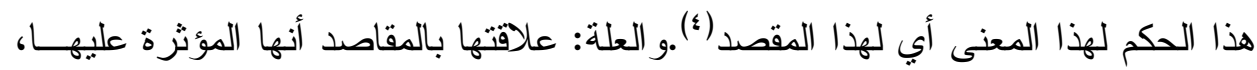

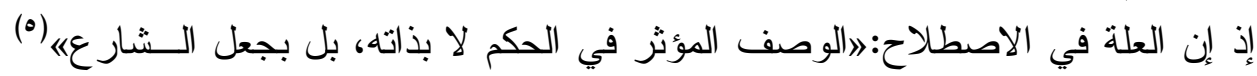

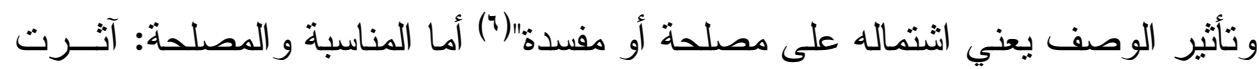

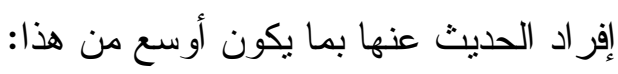
المطلب الأول: المناسبة: المان

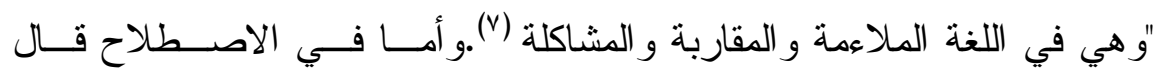

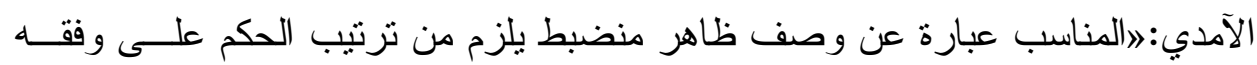
حصول ما يصلح أن يكون مقصوداً من شرع ذللك الحكمه (^).

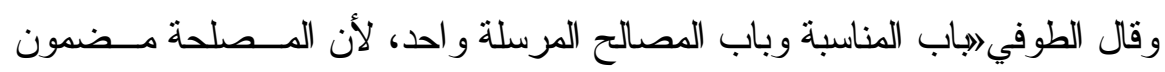

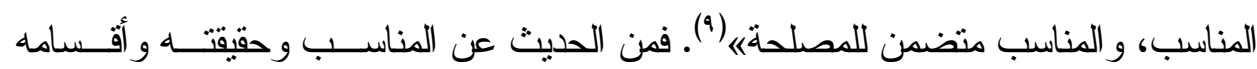

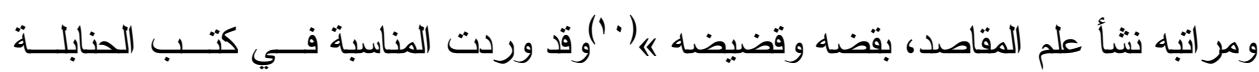

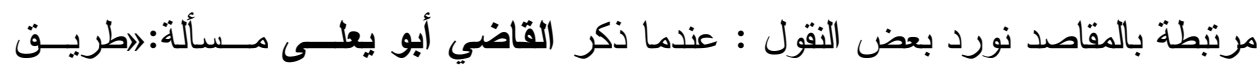

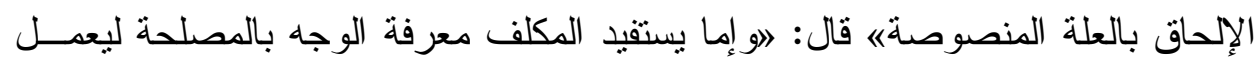

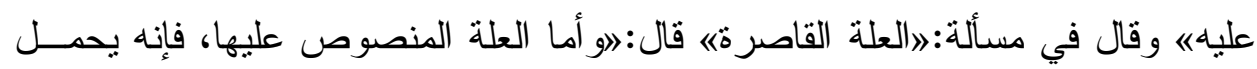

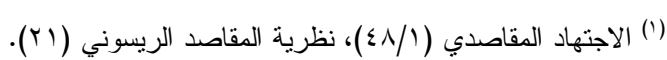

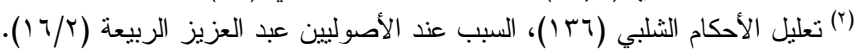

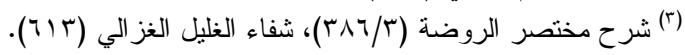

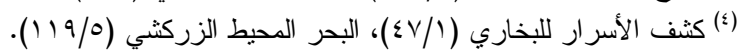

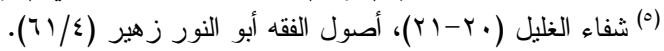

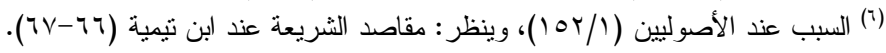

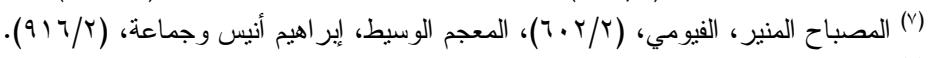

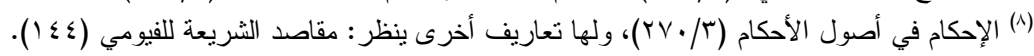

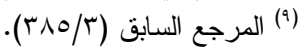

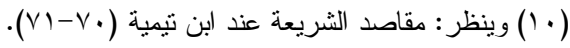


الأمر فيها على أنها بيان لعلة المصلحة التي لأجلها أبيح أو حظر، و وعلـلـل المــصالح لا

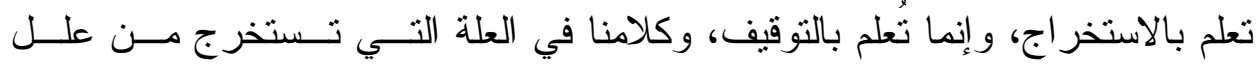

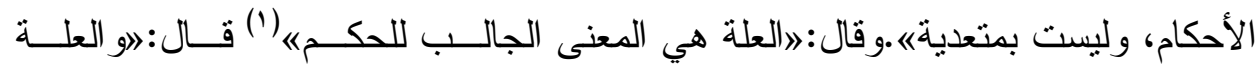

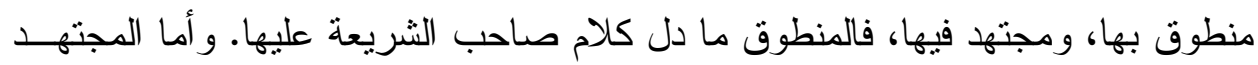

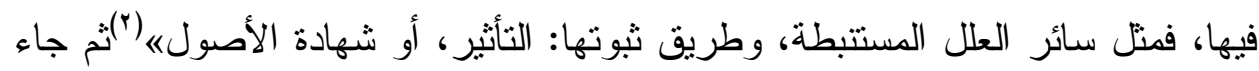

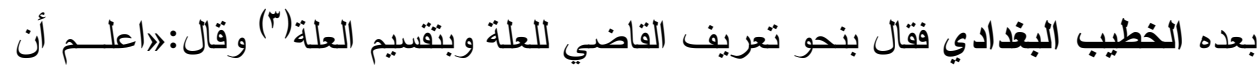

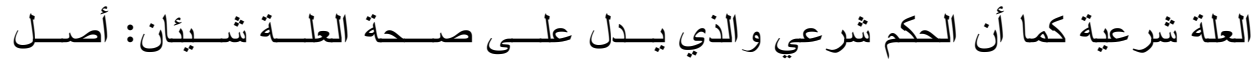
و استتباط،..(؛)وقال أبو الخطاب: 》لا فائدة في معرفة العلة إلا لتعرف المصلحة فيهــا،

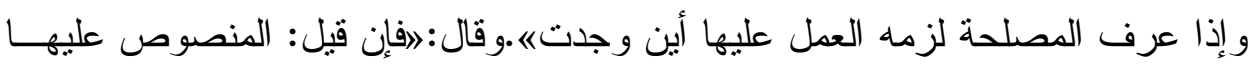

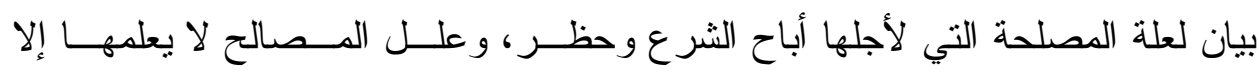

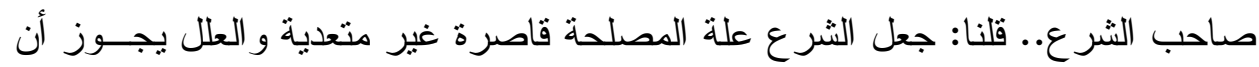

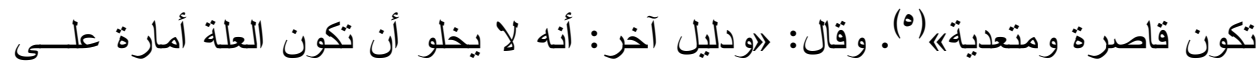

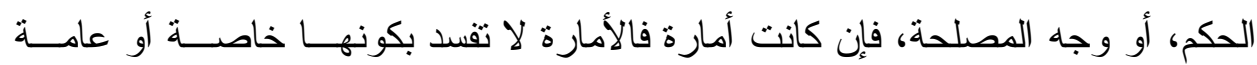

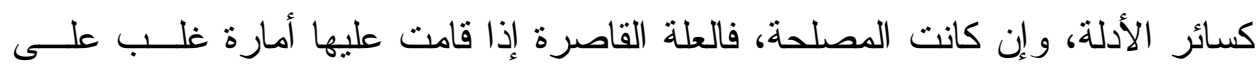

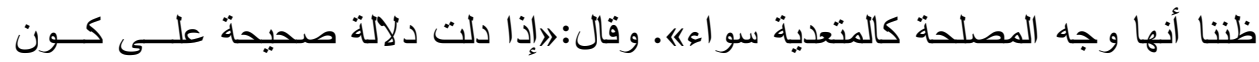

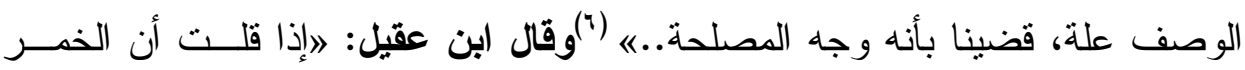

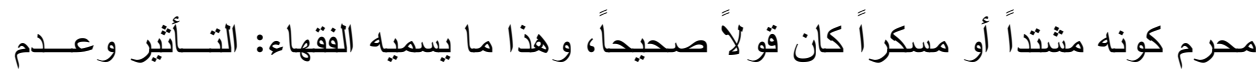

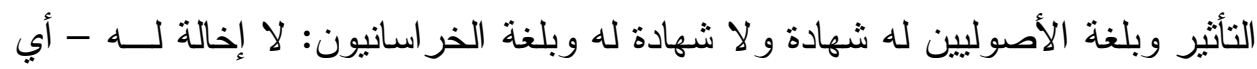

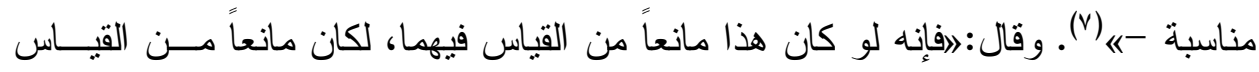

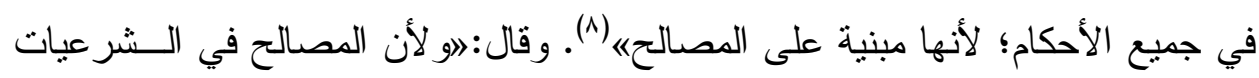

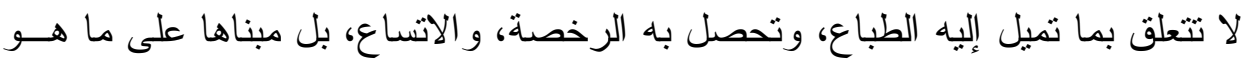

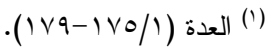

$$
\begin{aligned}
& \text { (r) (r) العدة (1) (العدة (1) (1) ). }
\end{aligned}
$$

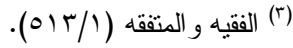

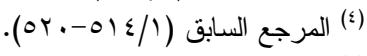

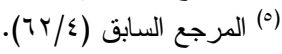

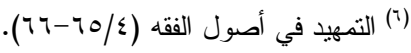

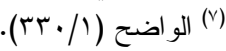

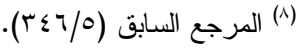


الأنفع لهم و الأصلحه" (')ث جاء ابن قدامة ففصل القول في المناسبة وعلاقتها بالمقاصد أكثر

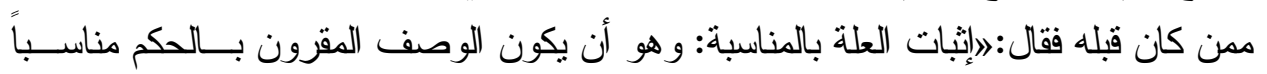

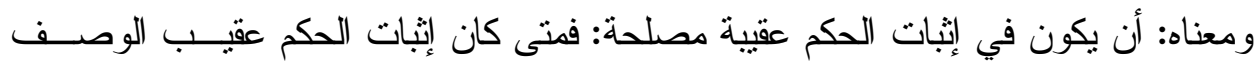

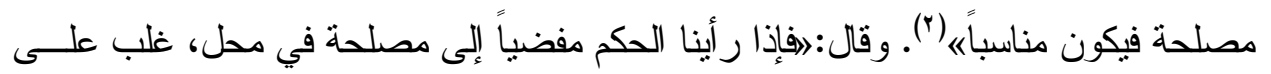

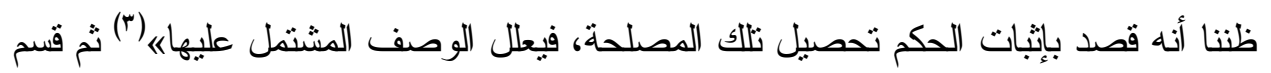

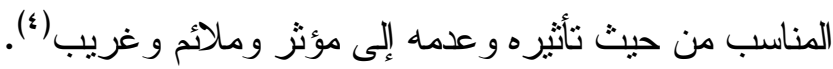

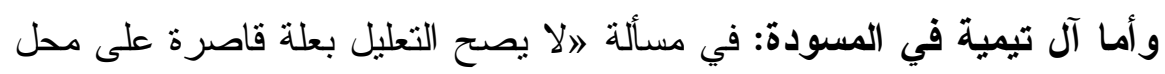

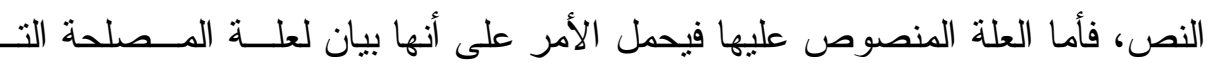

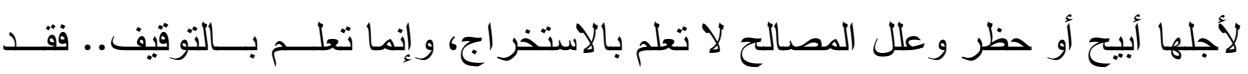

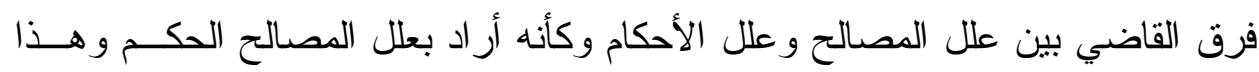

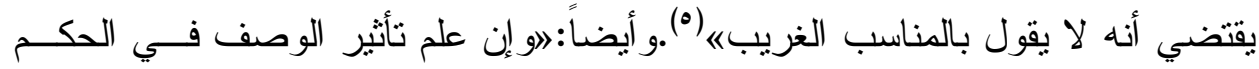

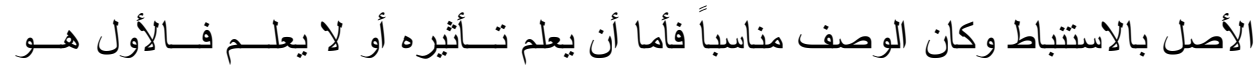

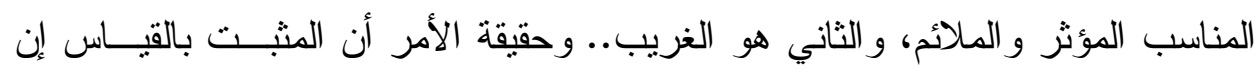

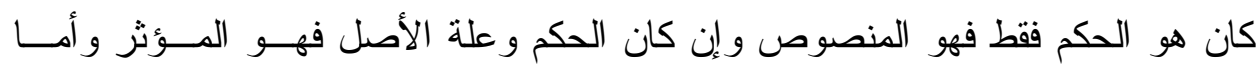

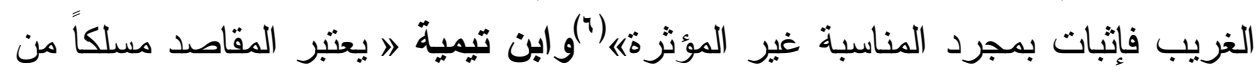

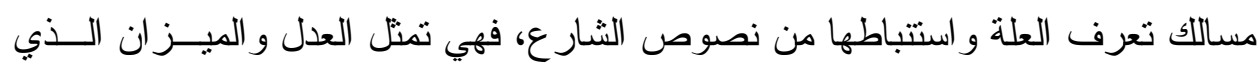

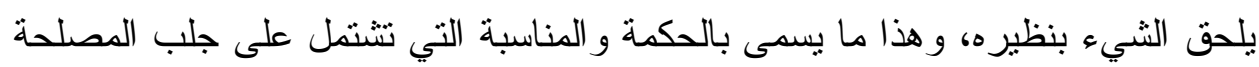

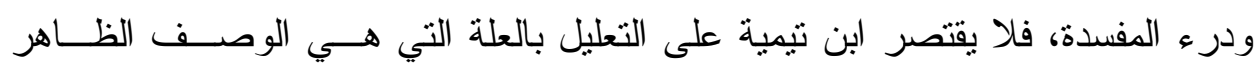

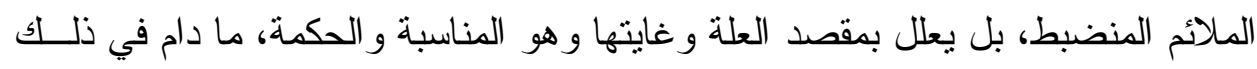

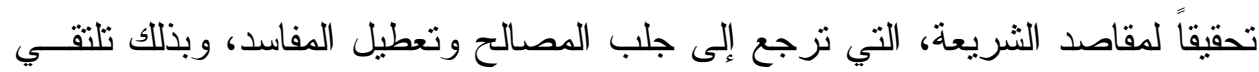

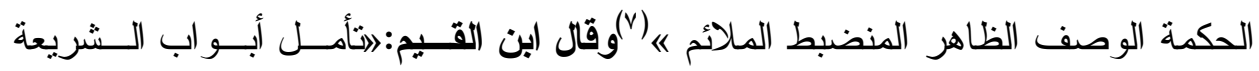

$$
\begin{aligned}
& \text { (1) المرجع السابق (r/1/0). }
\end{aligned}
$$

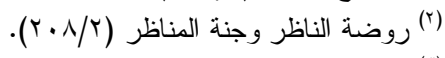

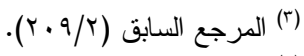

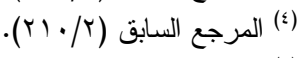

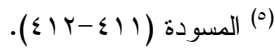

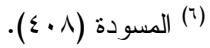

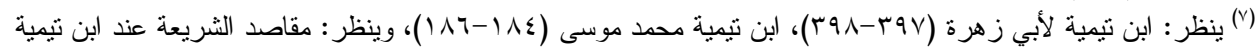


ووسائلها وغاياتها كيف تجدها مشحونة بالحكم المقصودة، و الغايات الحميدة التـي شــرعت

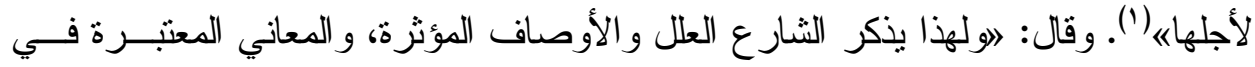
الأحكام القدرية والثرعية والجزائية ليذل بذلك على تعلق الحكم بها أين وجدت و اقتــــائها

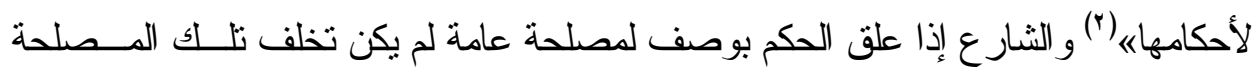

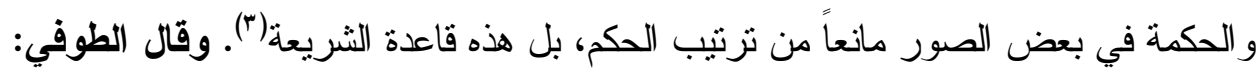

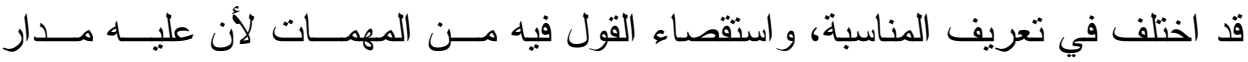

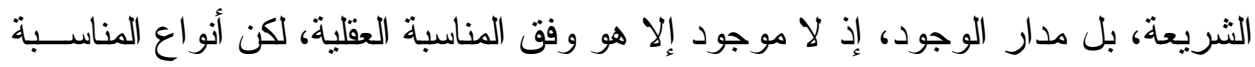

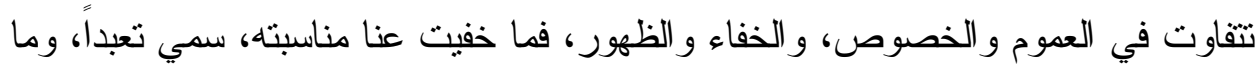

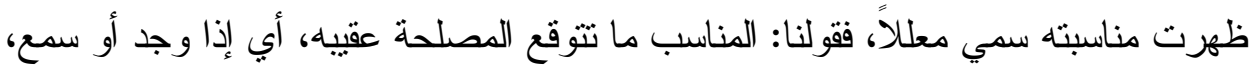

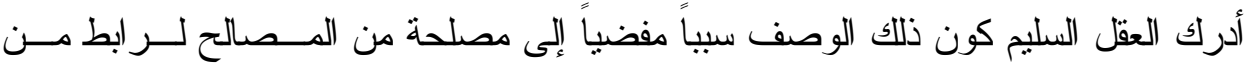

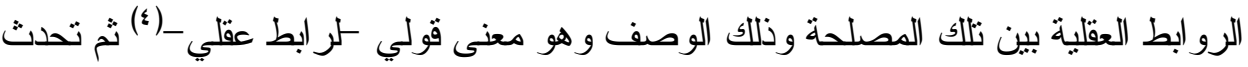

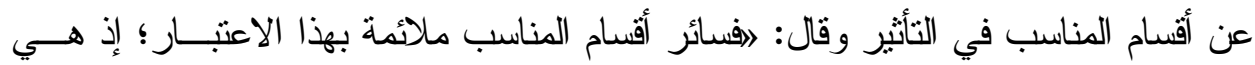

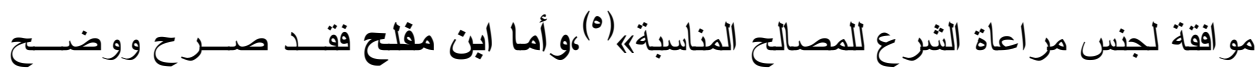

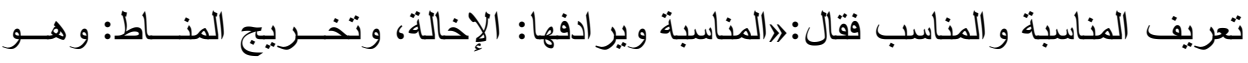

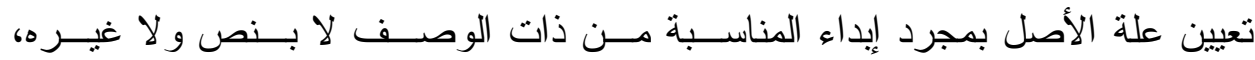
و المناسب: وصف ظاهر منضبط يلزم من تزتيب الحكم عليه ما يصلح كونه مق مصوداً

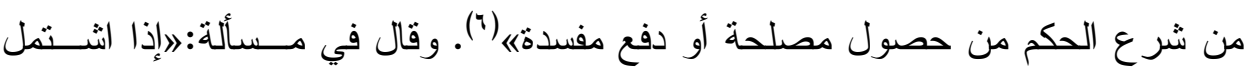

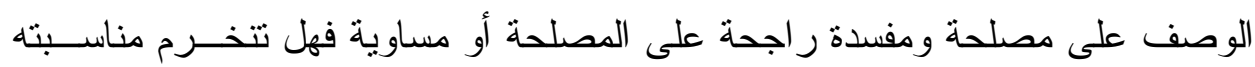

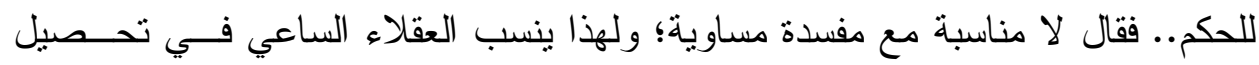

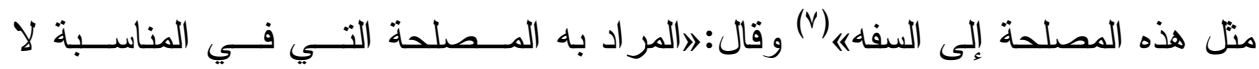

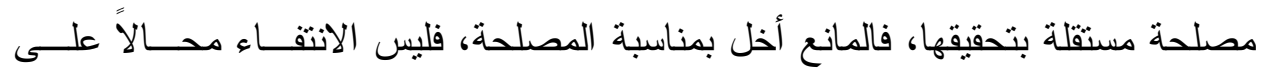

\begin{tabular}{|c|}
\hline (') شفاء العليل (•rT). \\
\hline (r) أعلام الموقعين (10r/1). \\
\hline (r) المرجع السابق (r/ \& ه). \\
\hline (£) شرح مختصر الروضة (r/r/r). \\
\hline 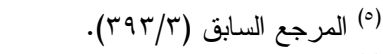 \\
\hline رل ابن مفلح (TV9/T rVa). \\
\hline ول ابن مفلح (Y/ Y Y I). \\
\hline
\end{tabular}


المفسدة مع المناسبة لفوات شرطهاه (')ثم جاء بعد هؤ لاء الفتوحي فحدد المناسبة وذكـــر

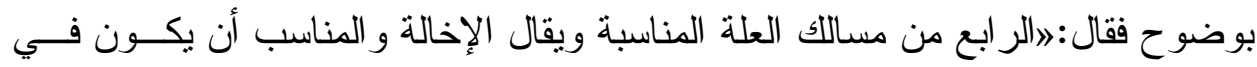

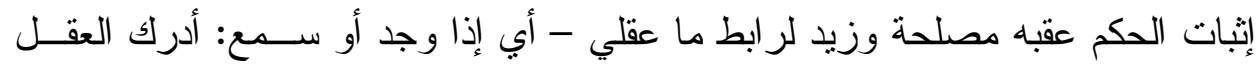

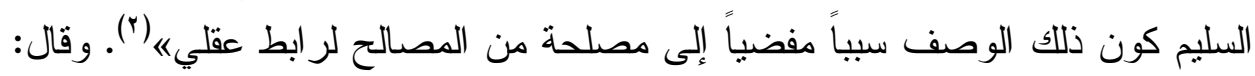

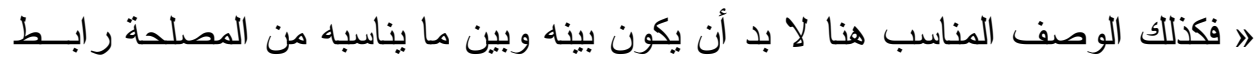

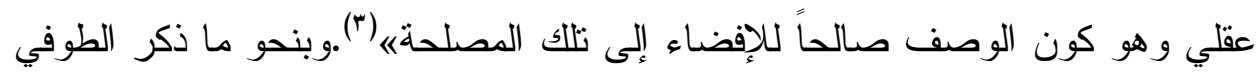

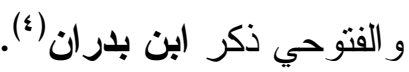
المطلب الثاني: المصلحة المرسلة:

״ المصلحة لغة: الصلاح، و المصلحة واحدة المصالح، كالمنفعة لفظاً ومعنى (॰).

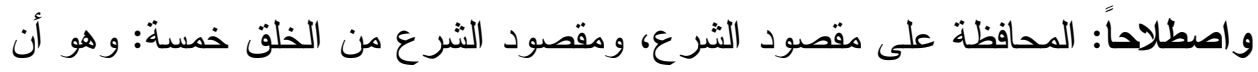

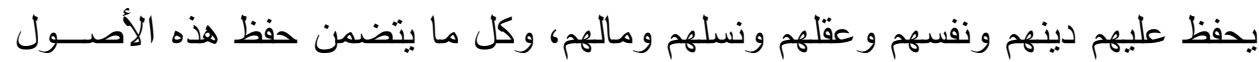

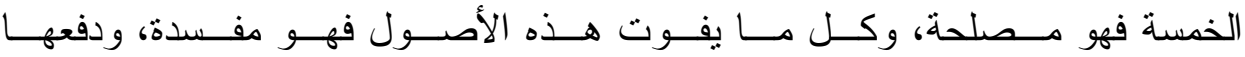

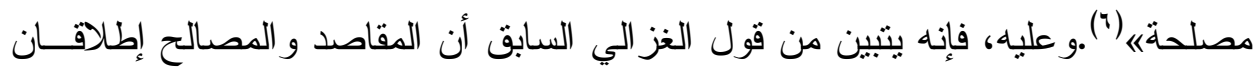

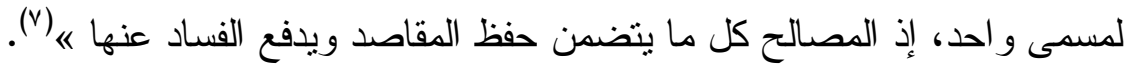
و الحق أن المذاهب كلها تعمل بالمصلحة المرسلة، وإن قرروا في أصولهم أنهـــا غيــر

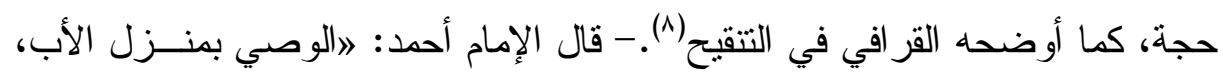

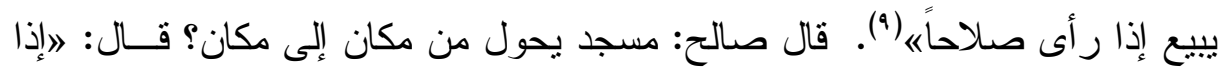

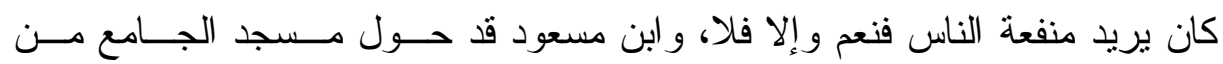

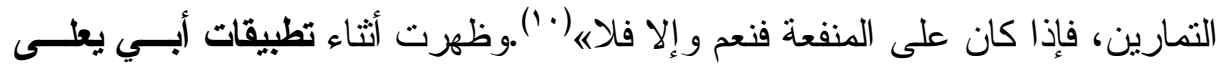

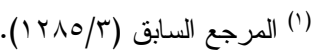

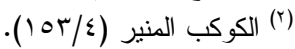

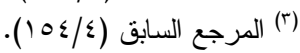

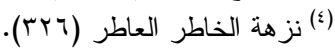

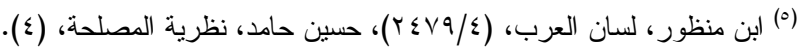

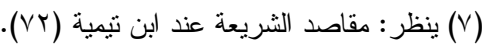

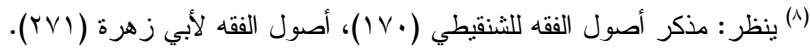

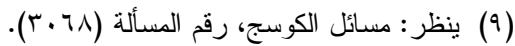

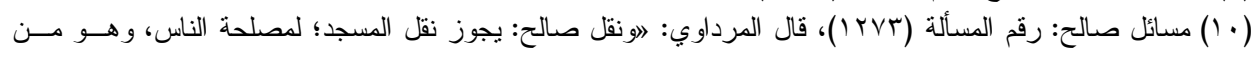

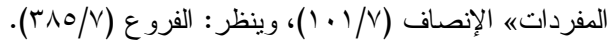


وأبو الخطاب وكلامه عن المصلحة(1)؛ قال البذدادي: الو لأن الشرع لم يوضع على العادة

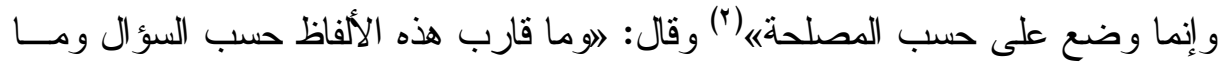

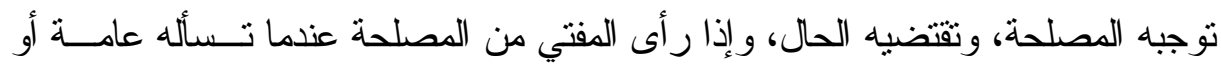

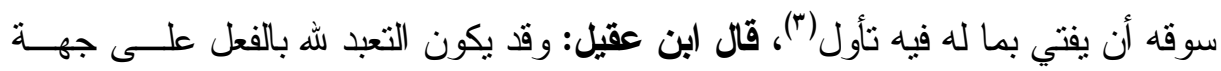

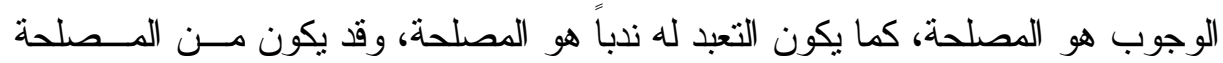

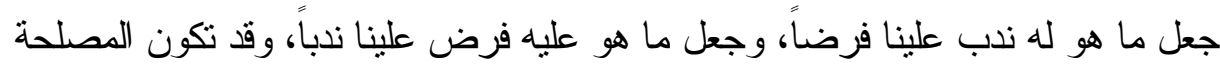

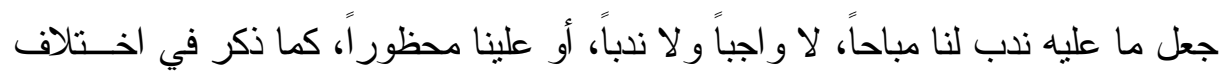

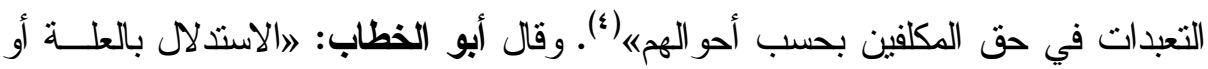

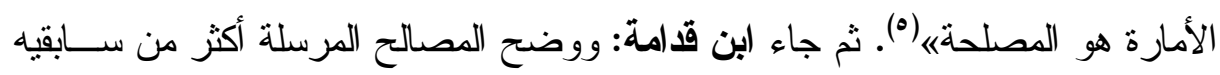

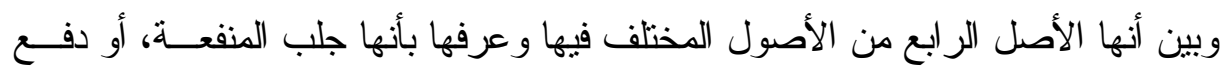

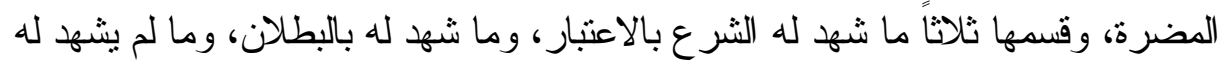

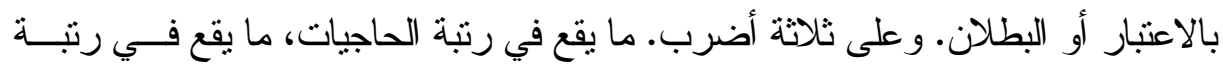

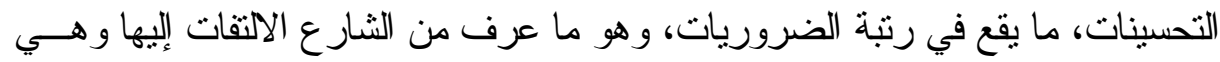

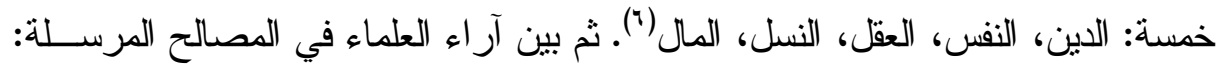
فذهب مالك، وبعض الثنافعية إلى أن هذه المصلحة حجة؛ لأنا قد علمنا أن ذلك من مقاصد

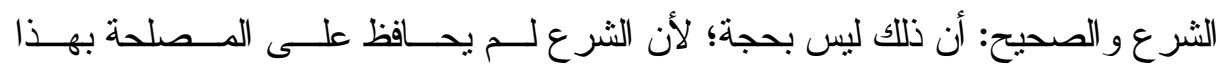

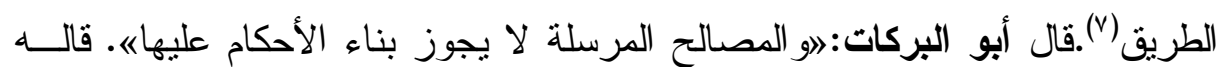

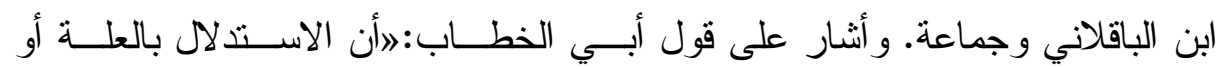

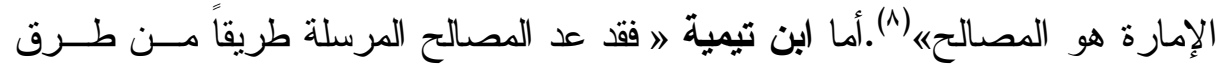

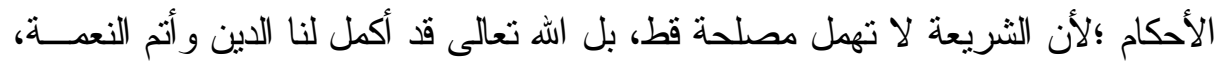

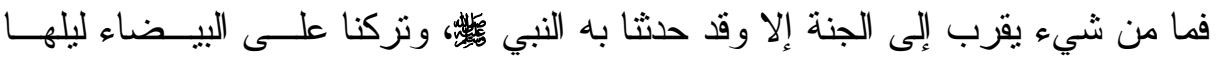

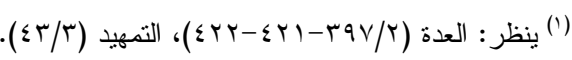

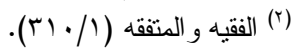

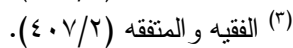

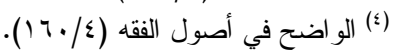

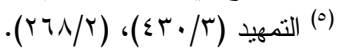

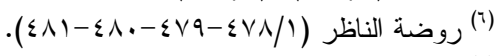

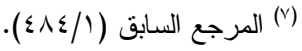

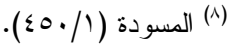


كنهار ها لا يزيخ عنها بعده إلا هالّك، لكن ما اعتقده العقل مصلحة وإن كان الثرع لم يرد

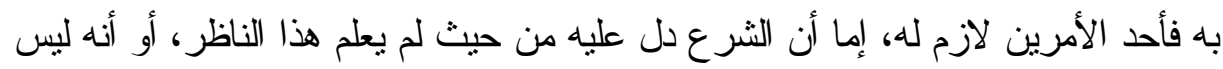

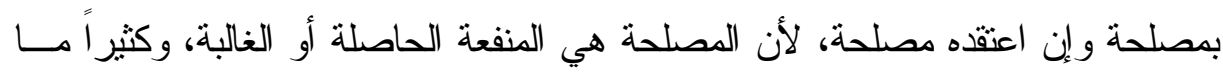

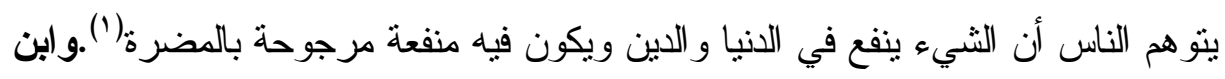

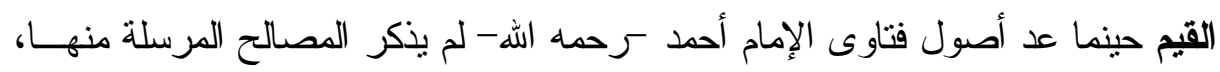

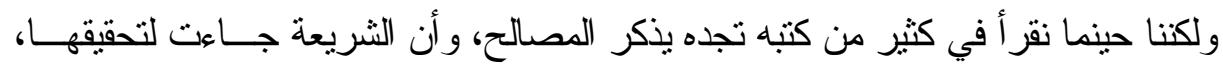

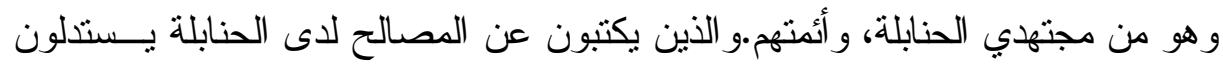

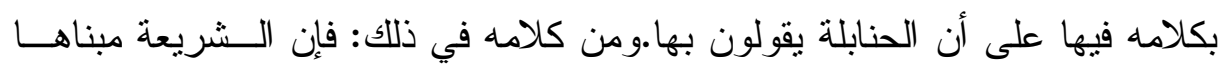

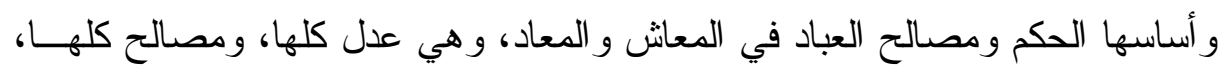

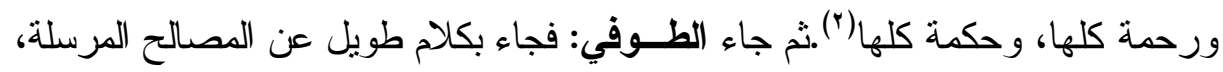

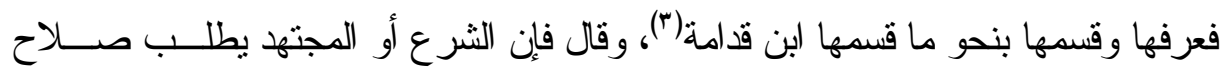

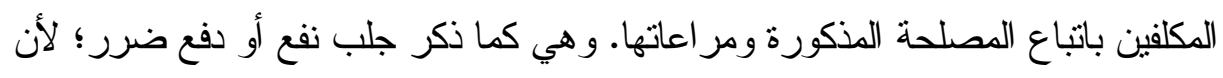

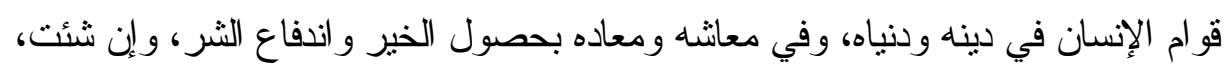

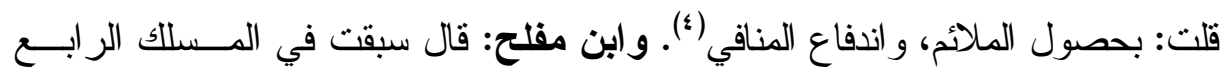

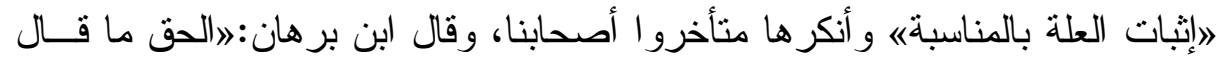

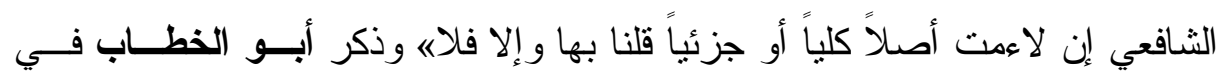

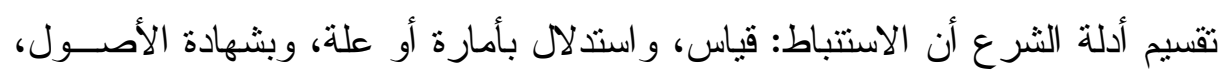

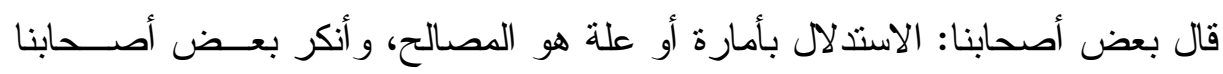

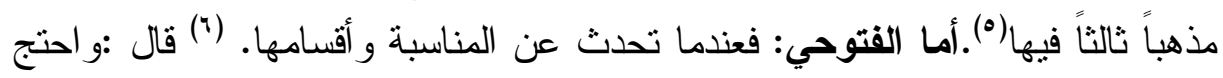

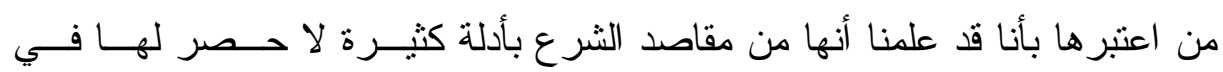

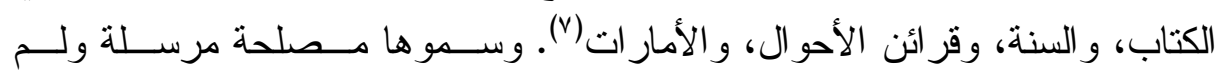

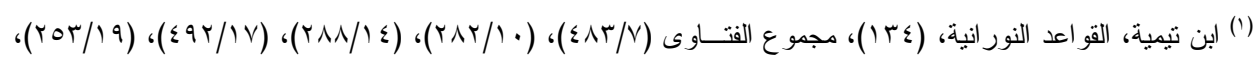

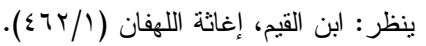

$$
\begin{aligned}
& \text { (r) إعلام الموقعين (r/ ( ) ). }
\end{aligned}
$$

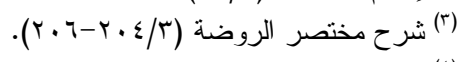

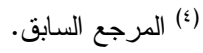

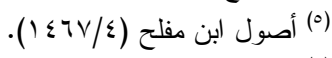

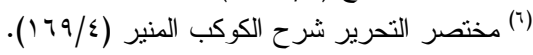

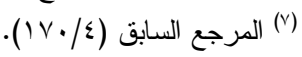




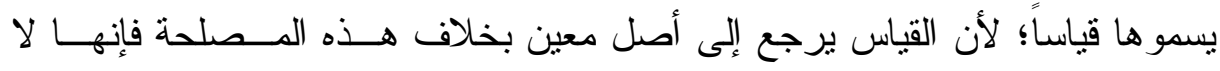

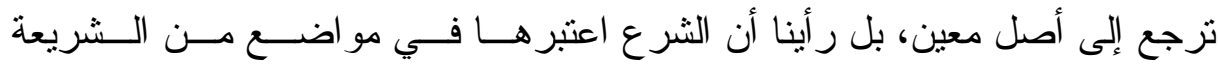

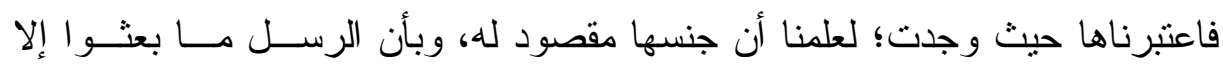

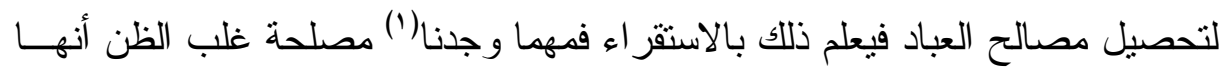

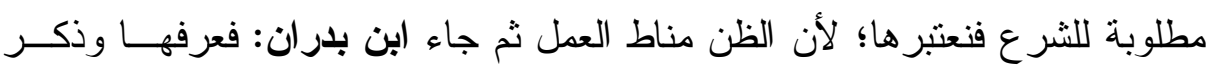

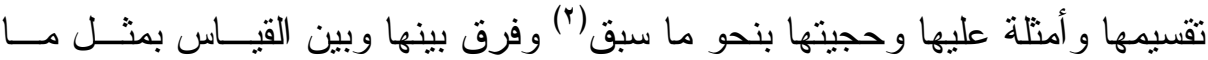
سبقه الفتوحي (َّ) وذكر رأي الطوفي و أنها حجة ودأ).

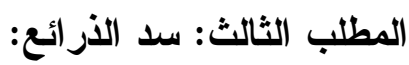

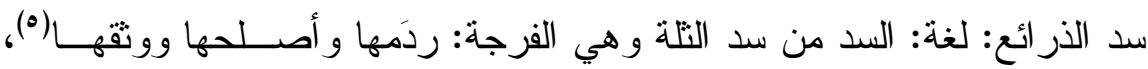

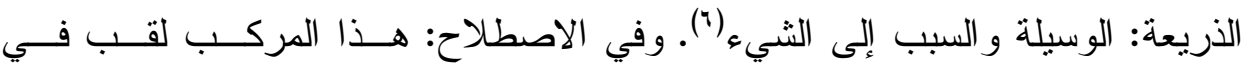

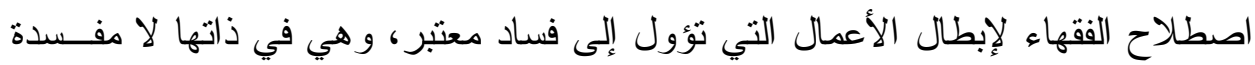

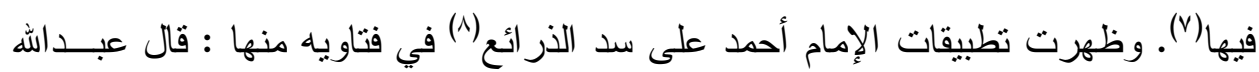

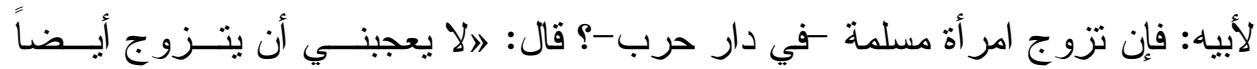

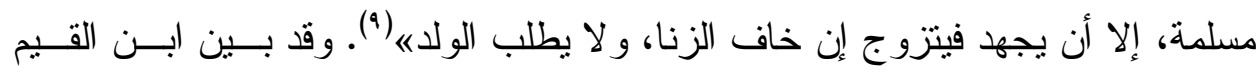

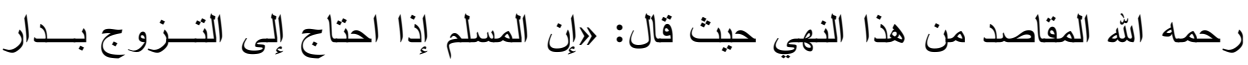

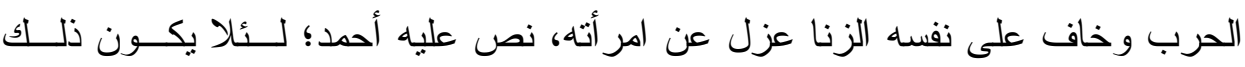

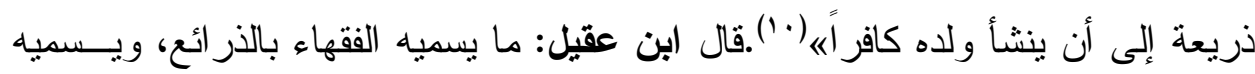
أهل الجدل: أنه المستحيل في العقل أو الشرع منل منع تزويج المسلم بالأمة الكافرة لئلا

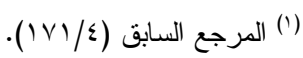

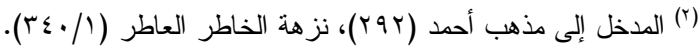

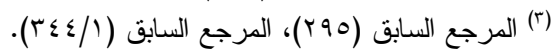

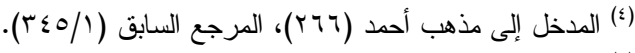

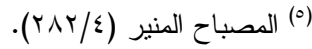

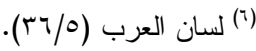

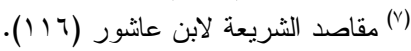

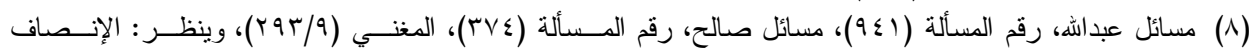

$$
\text { (10- } 1 \leq / \Lambda)
$$

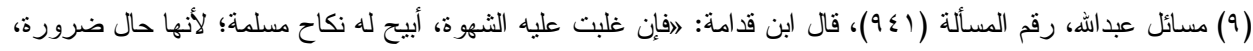

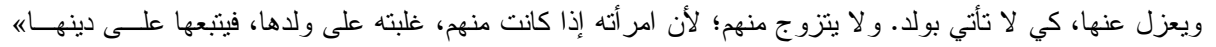




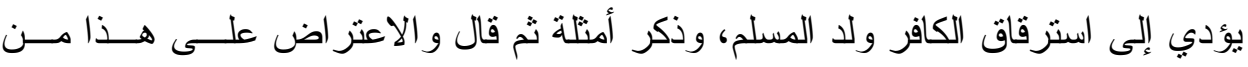

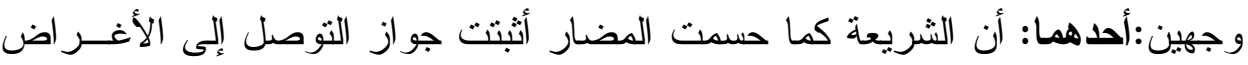

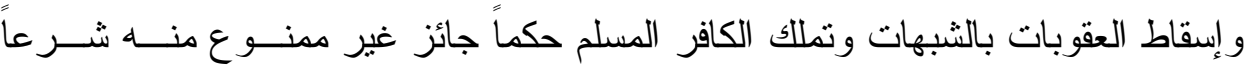

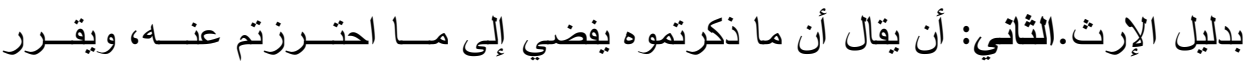

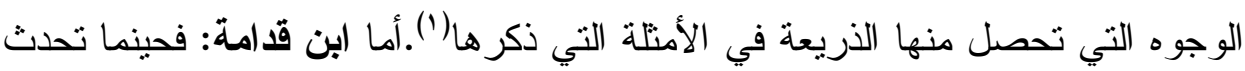
في مقدمة الكتاب ذكر أن الله تولى عباده من أول الأمر بالعناية والنوجيه، وبيان المنهج

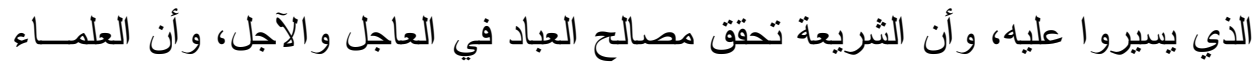

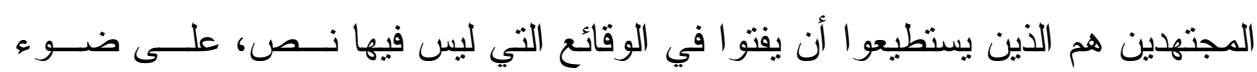

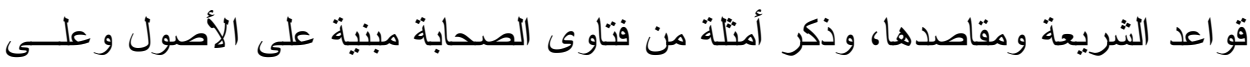

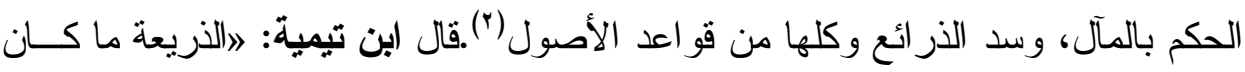

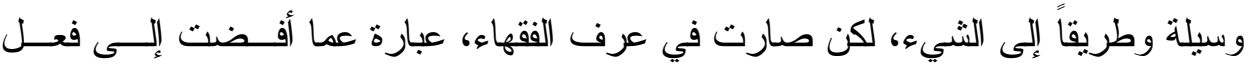

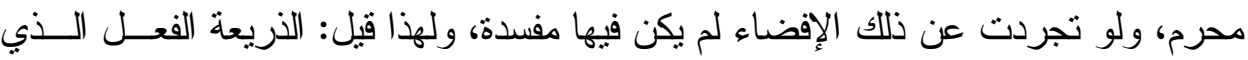

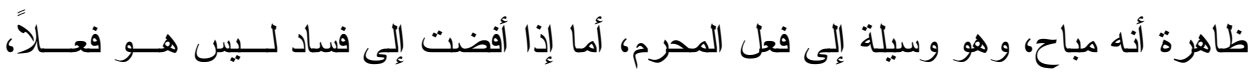

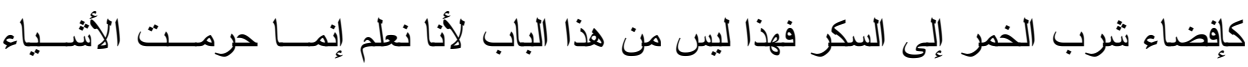

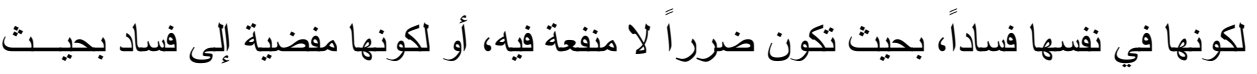

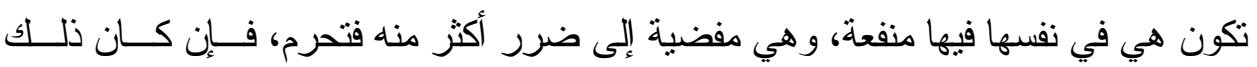

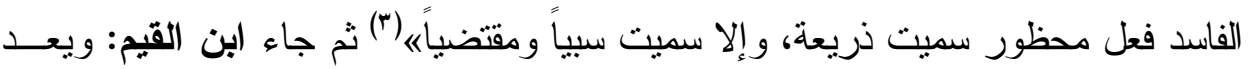

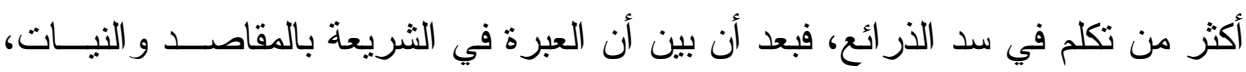

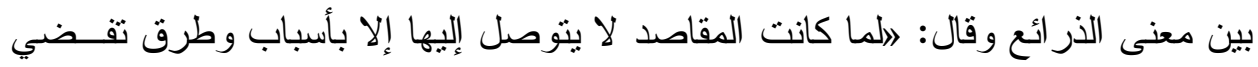

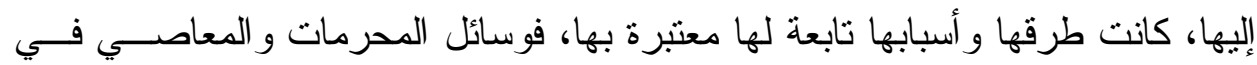

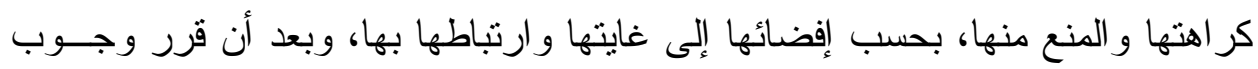

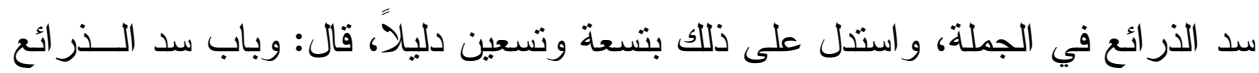

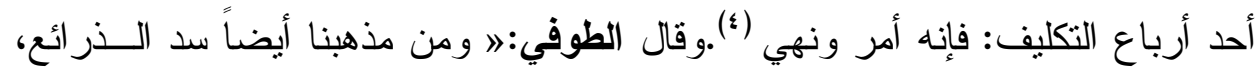

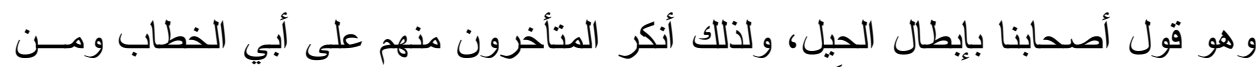

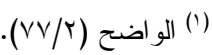

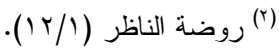

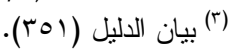

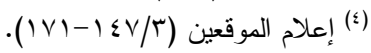


تابعه عقد باب في كتاب الطلاق يتضمن الحيلة على تخليص الحالف مــن يمينــه فــي

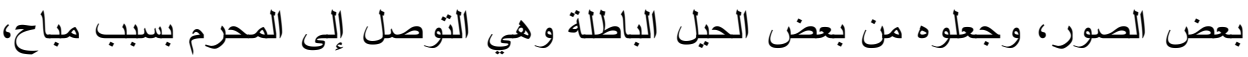

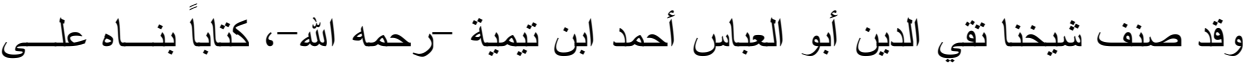

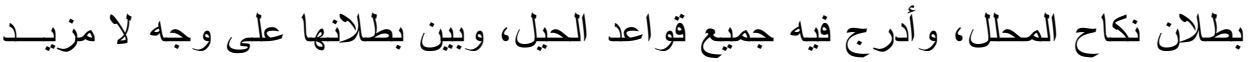

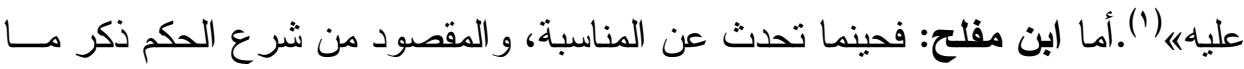

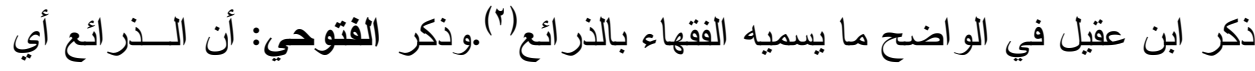

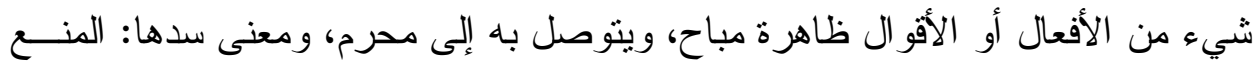

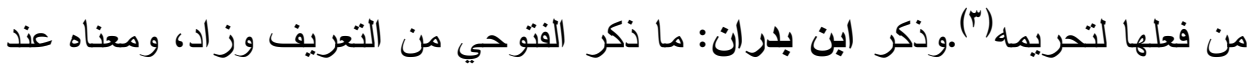

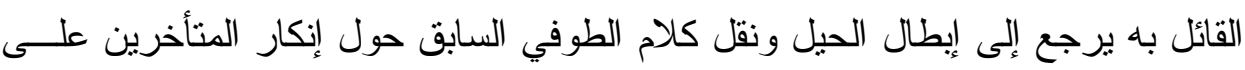

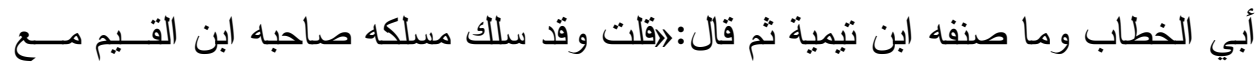

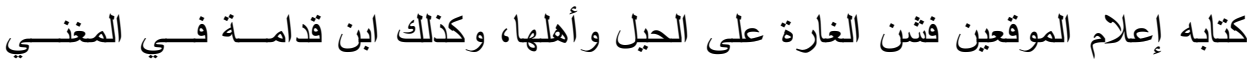

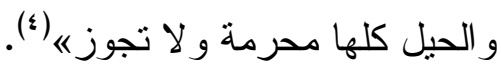
المطلب الر ابع: الاستحسان:

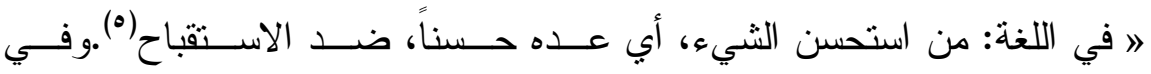
الاصطلاح: ذكر الغز الي ثلاث تعريفات له: الأول: ما يستحسنه المجتهذ بعقله. وهذا لاهن لا

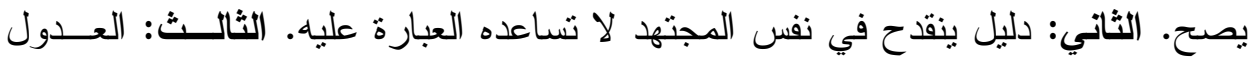

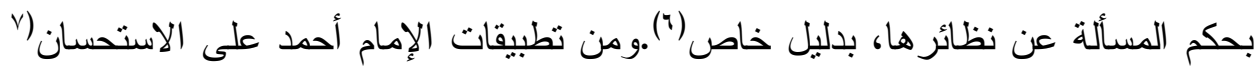

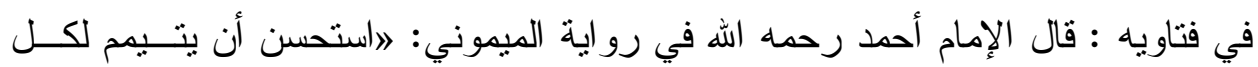

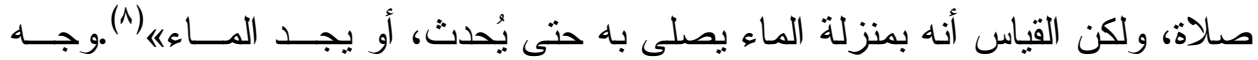

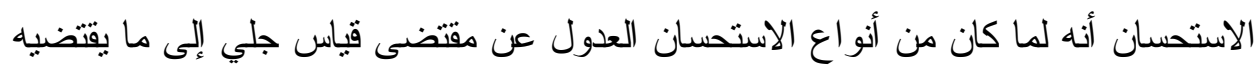

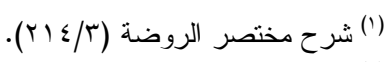

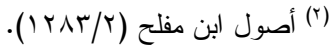

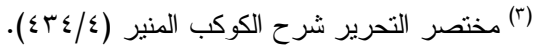

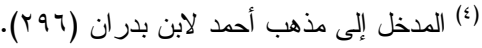

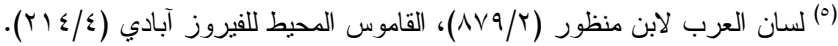

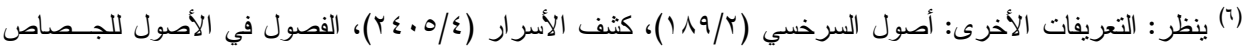

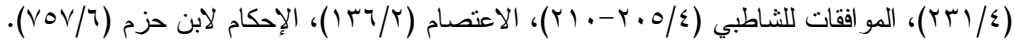

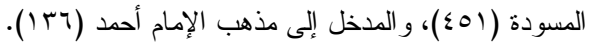

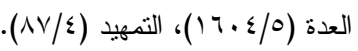




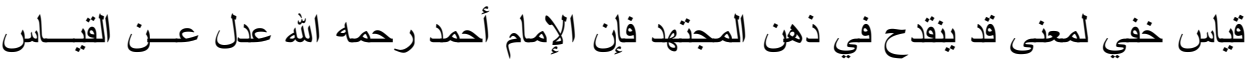

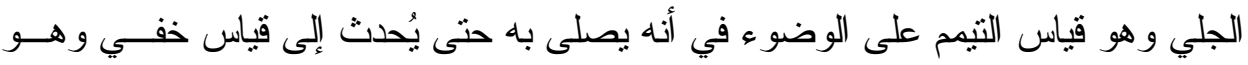

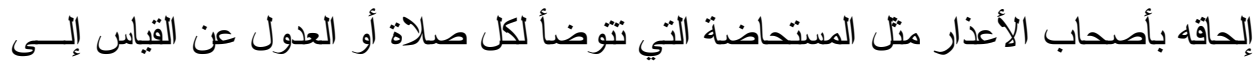
قاعدة، والقاعدة هنا أن الرخصة تقرر بقرها وتتجدد بتجدد موجبها.ذكر القاضي أبو يعلى:

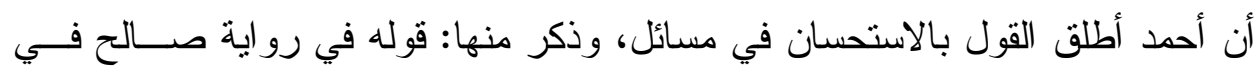

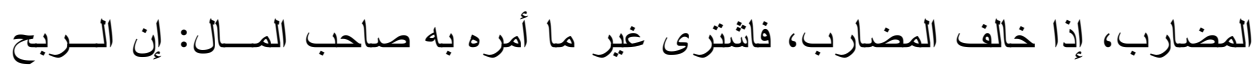

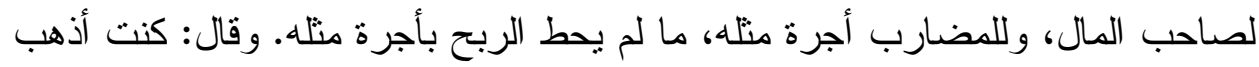

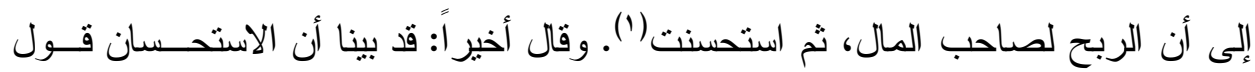

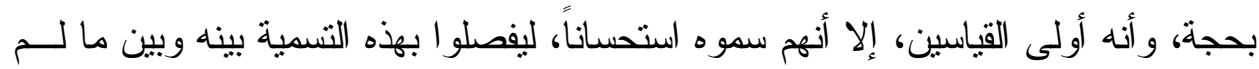

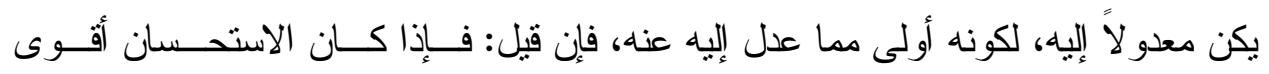

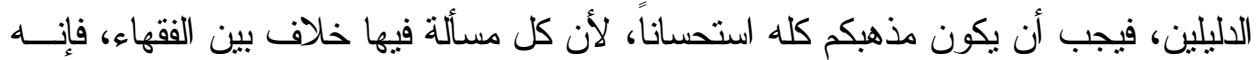

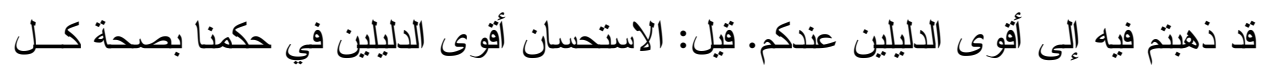

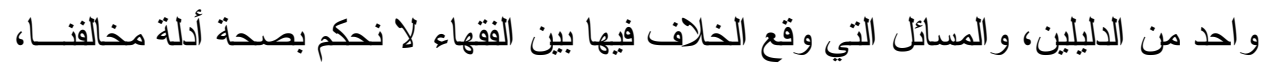

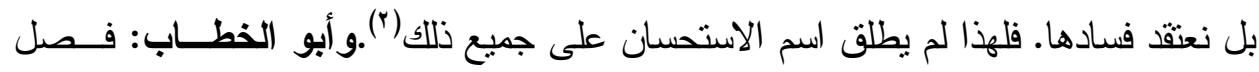

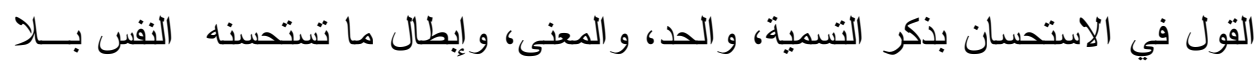

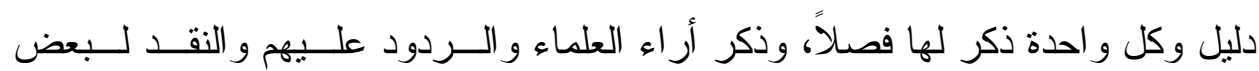

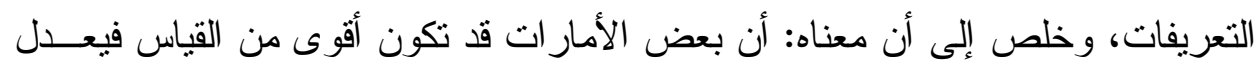

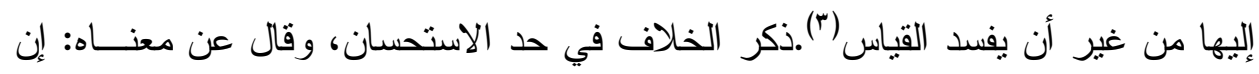

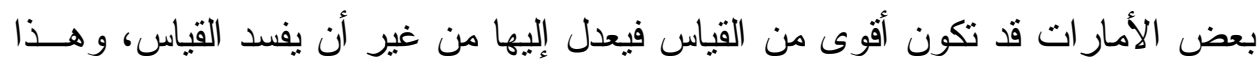

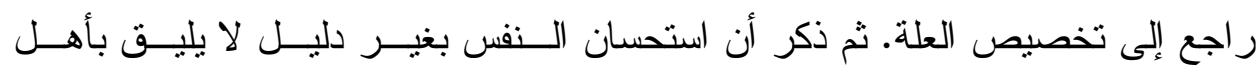

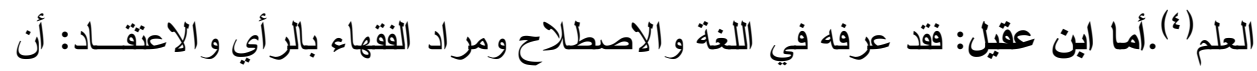

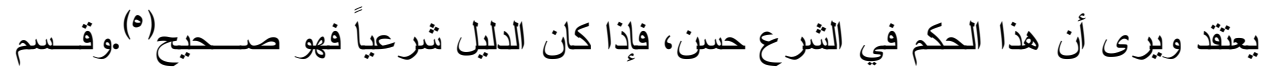

(1) لعل المر اد: ثم استحسنت أن يكون الربح بينهما، ولعل معنى العبارة السابقة: (اما لم يحط الربح بأجرة منله|《: ما لم يكن الربح أقل من أجرة المثل، فيكون حينئذ بينهما.

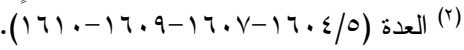

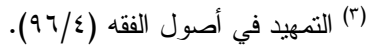

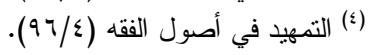
(0) الواضح (1/... (1). 
الاستحسان إلى ثلاثة أقسام، فقال: في ذلك: وجملة ذلك أنه ثلاثثة أقسام:أحدها: ترك القيــاس

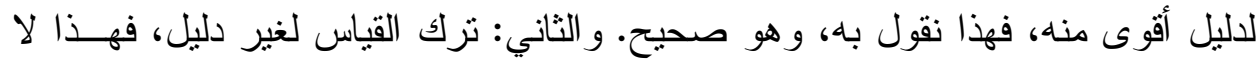

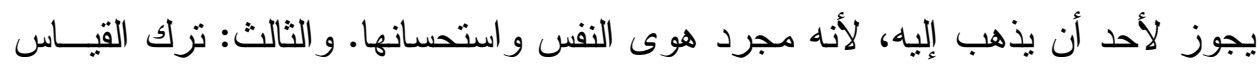

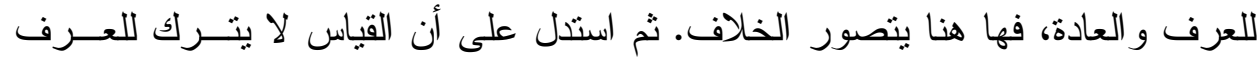

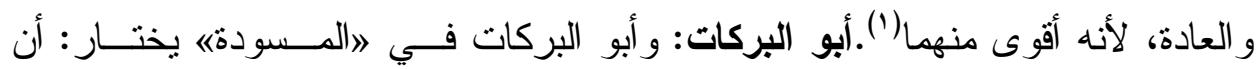

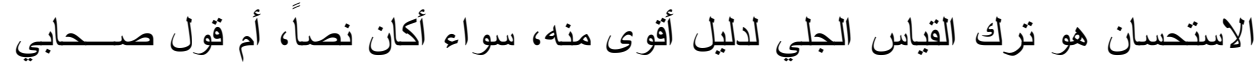

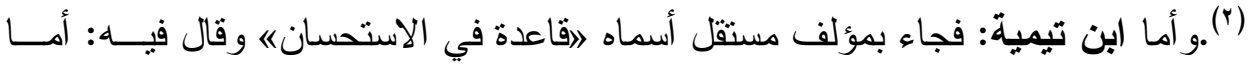

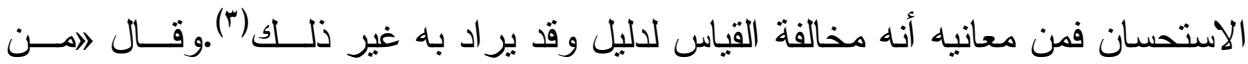

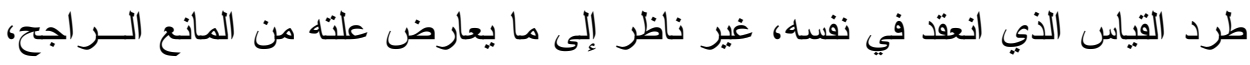

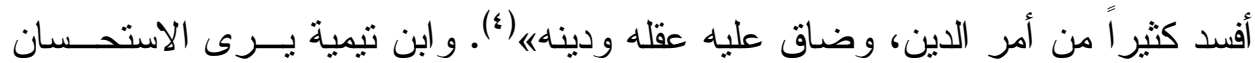

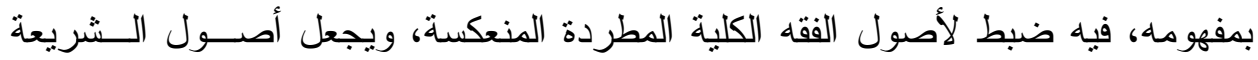
ومقاصدها جارية على أصول ثابتة منو ازنة ومنضبطة لا تتاقض فيها(ه)

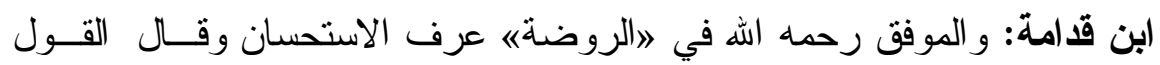
بالاستحسان مذهب أحمد كرحمه اله-، وهو أن نترك حكماً إلى حكم هو أولى منه، وهذا

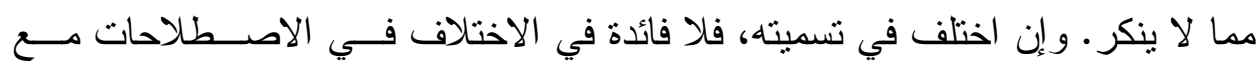

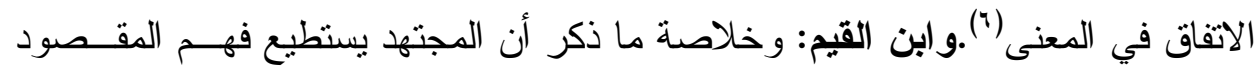

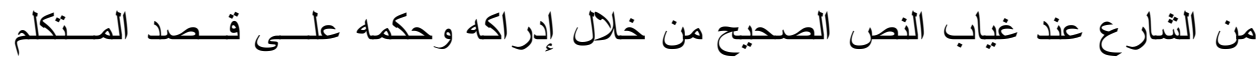

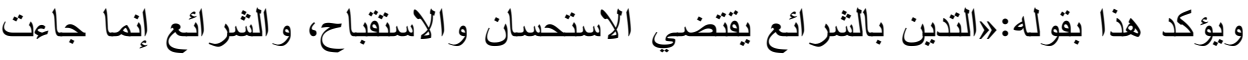

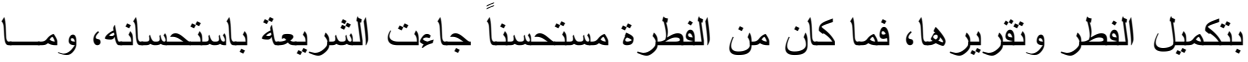

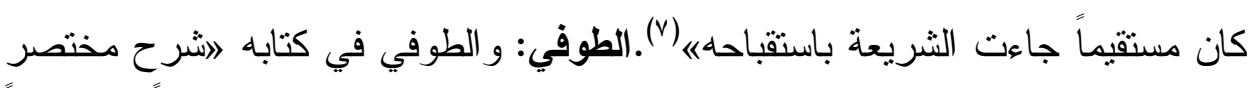

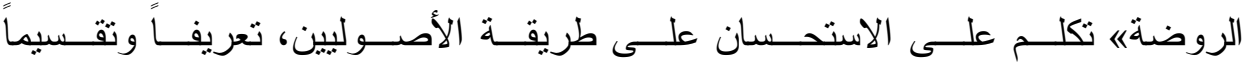

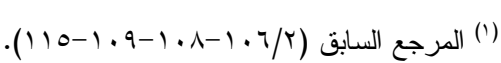

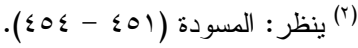

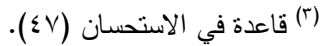

$$
\begin{aligned}
& \text { () (8) القو اعد النور انية (100). (100). }
\end{aligned}
$$

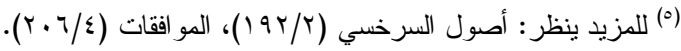

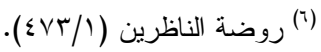

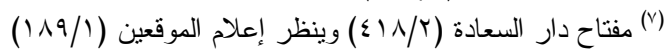


و استدلالاً (1).أما (بن مفلح: فقال الاستحسان ترك قياس لقياس أقوى منه، وقيـلـل عـدول عن حكم، و الدليل إلى العادة لمصلحة الناس، كثرب الماء من السقاء قلنا: ومستتده فعله

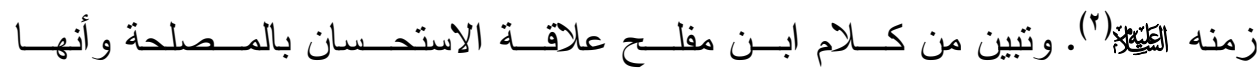
هي.الفتوحي: و الفتوحي ذكر الاستحسان وعرفه بنحو تعريف من سبقه، ونقل عن ابـن بـن

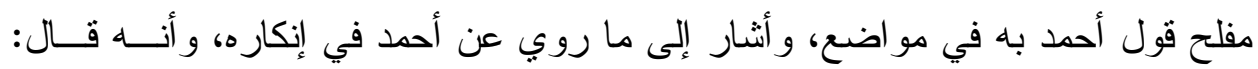

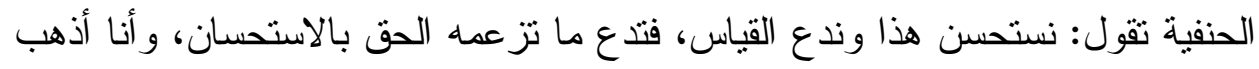

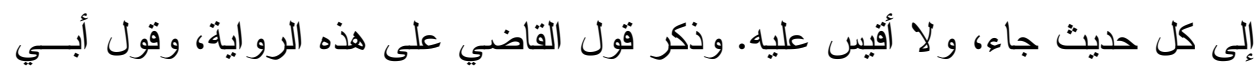

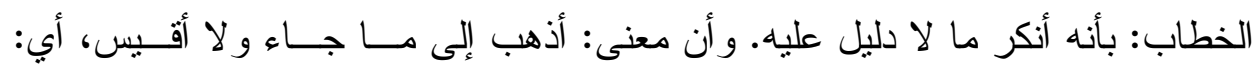

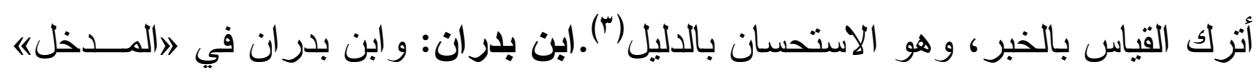

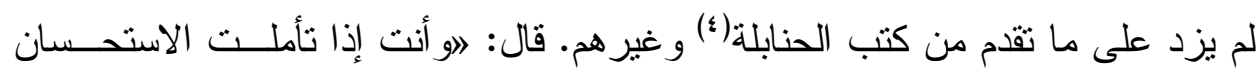

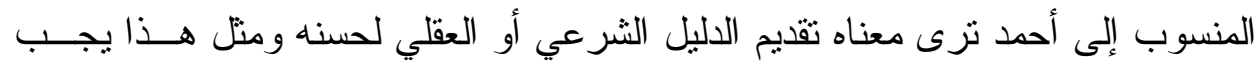

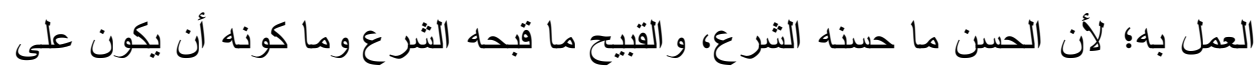

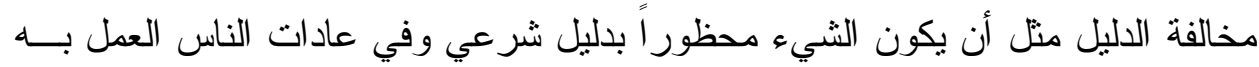

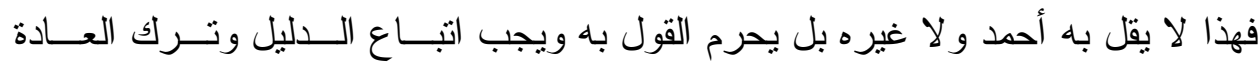

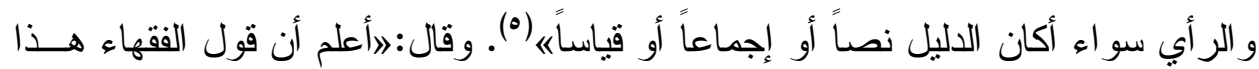

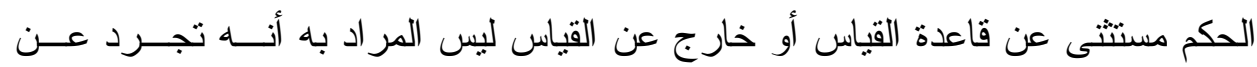

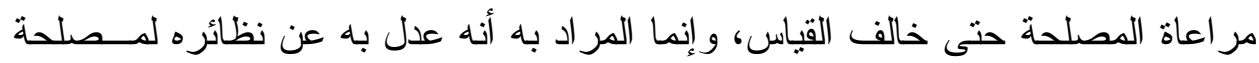
أكمل وأخص من مصالح نظائره على جهة الاستحسان الشرعي" (؟).

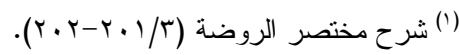

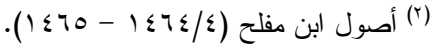

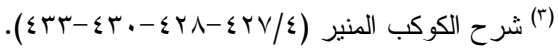

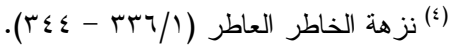

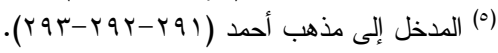

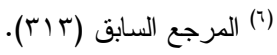




\section{المبحث الر ابع \\ التطبيقات المقاصدية عند الحنابلة \\ المطلب الأول: التطبيقات في العبادات: \\ 1- طو (ف الحائض:}

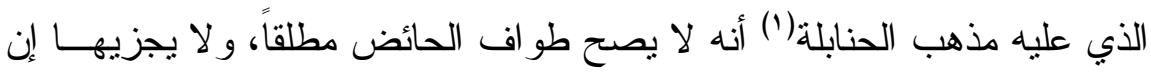

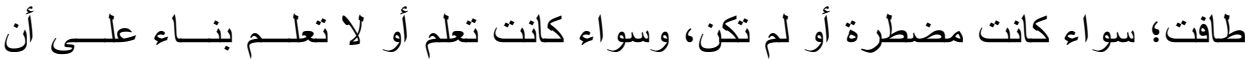

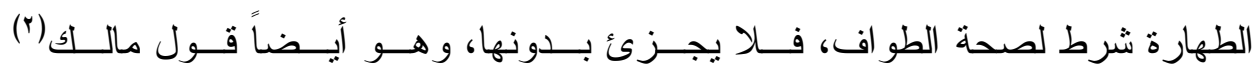

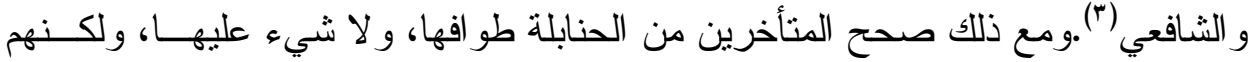
قيدوه بحال الاضطر ار فقط، وإلا فالأصل أنه لا يصح طو افها بلا عذر وهو قول قول الثيخ

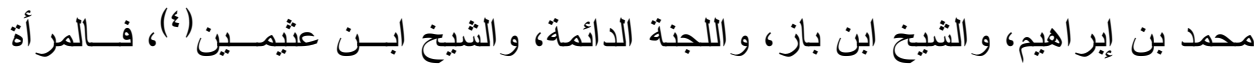

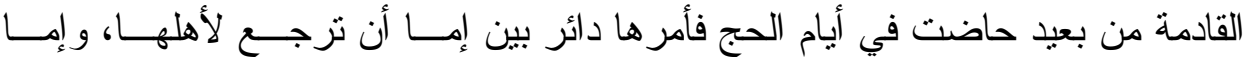

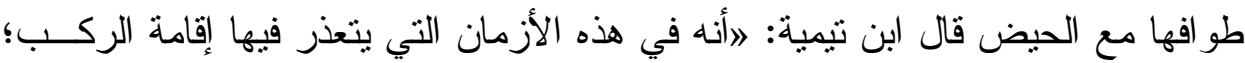

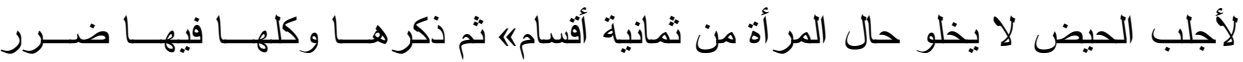

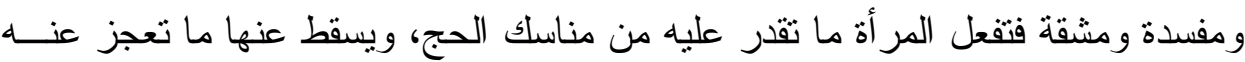

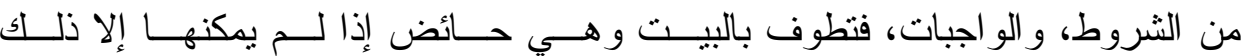

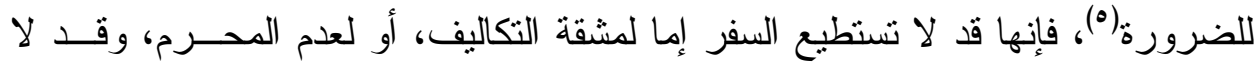
يقيى معها المحرم في مكة وفي هذا خوف من تركها بمفردها وقد تكون فقيرة لا نفقــة

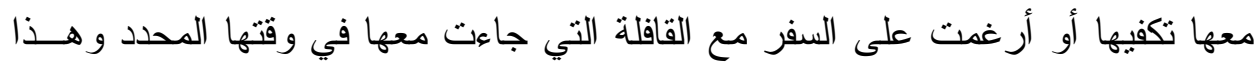

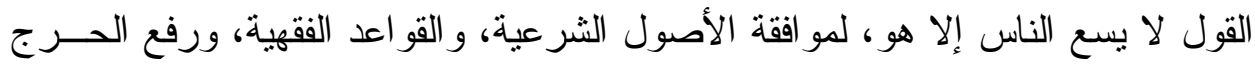

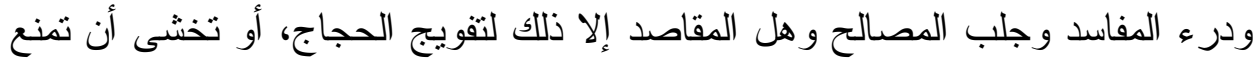
من الحج إلا بعد خمس سنوات وكلها أعذار مسوغة للعمل بالمقاصد.

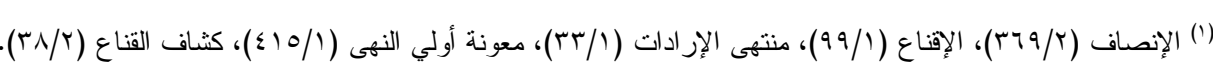

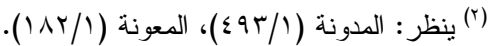

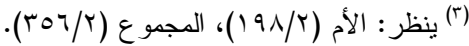

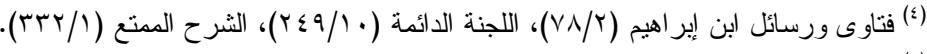

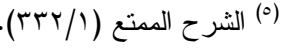




\section{المطلب الثاني: المعاملات المالية: صور من الحيل الممنوعة:}

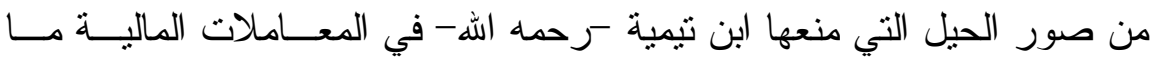

ا- الاحتبال على إسقاط حق الثريك في الثفعة، وذلك كأن يكون ثـــن المبيــع ألفــاً،

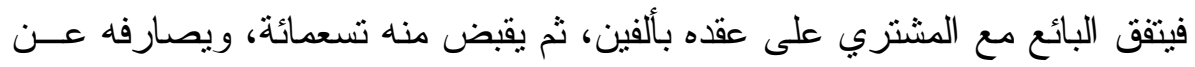

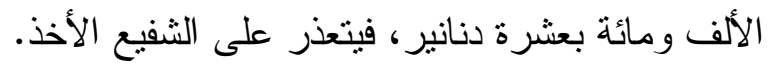

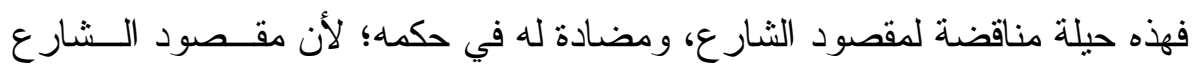
تكميل العقار للشريك؛ ليزول عنه ضرر الثركة و القسمة (1).

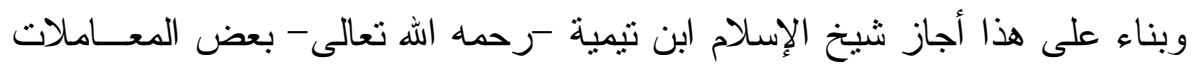

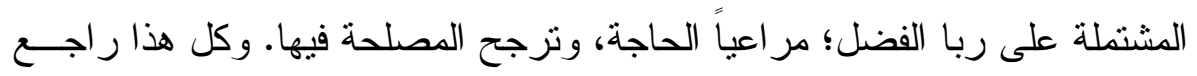
إلى إعمال المقاصد. 


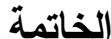

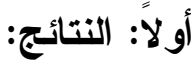

1- - الدقاصد له طوران: طور التأسيس، و التنظير ، و التأصيل قد تكلم فيه الأو ائل ولـــــ

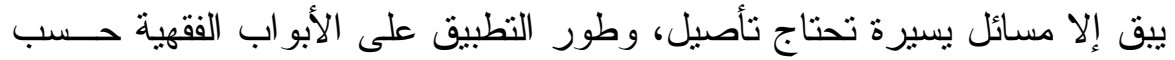
ما تم تأصيله وهو ضيق إلا في باب المعاملات.

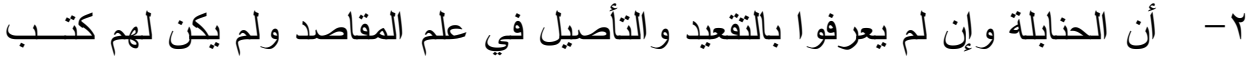
فيها، إلا أنهم عرفو ا بالتطبيق.

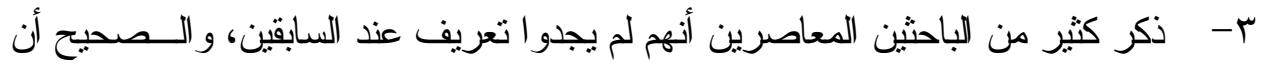
أول من عرفها الرازي في كتابه الكاثثف عن أصول الدالائل وفصول العلل.

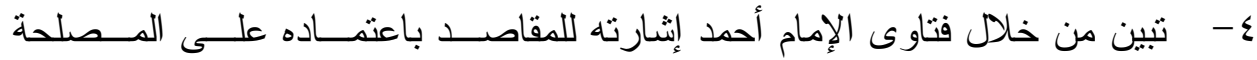

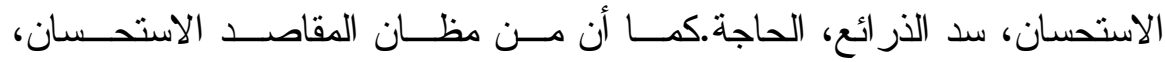

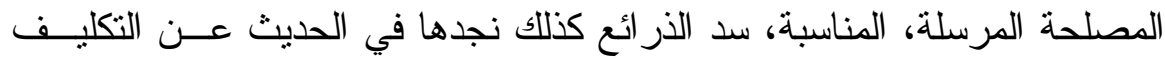
وشروطه، و الاستخلال، و الاسنقر اء وكذلك قو اعد الفقه كما فعل الفنوحي.

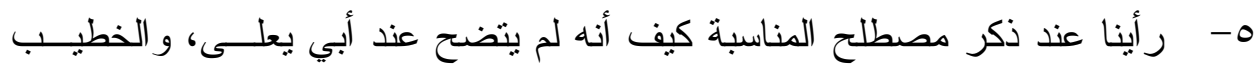

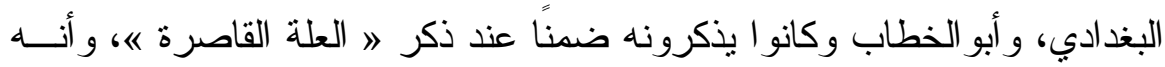

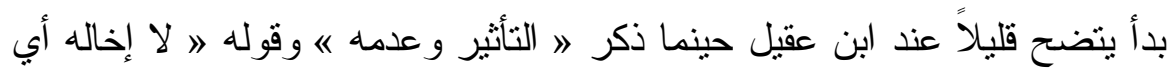
مناسبة ه ولما جاء ابن قدامة فصل القول في المناسبة، وعلاقتها بالمقاصد أكثر ممن كان قبله وذكر أقسام المناسب وتعريفها. وعند ابن تيمية وابن القيم و الطوفي

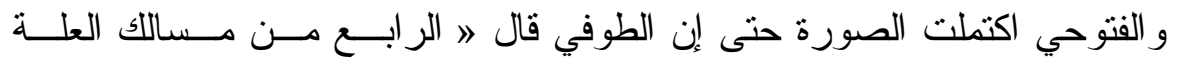

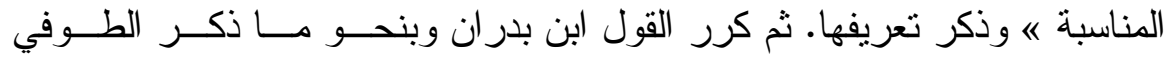
و الفتوحي ذكر.

7- و وعند ذكر مصطلح المصالح المرسلة بدأت عند أبي يعلى وأبو الخطاب علــى هيئــة

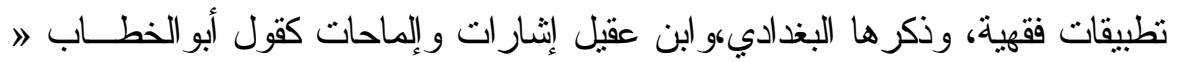
الاستخلال بالعلة هو المصلحة ه حتى جاء ابن قدامة وبين أنها الأصل الر ابع من الأدلة

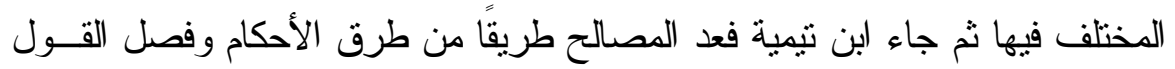




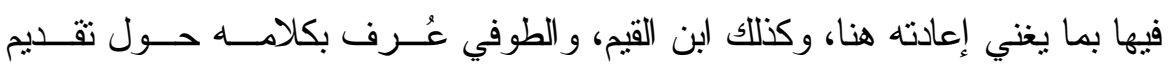

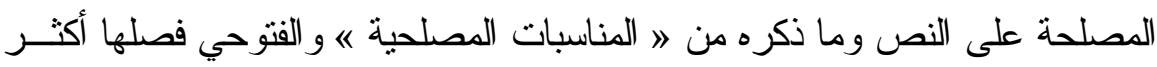

$$
\begin{aligned}
& \text { من سابقيه و أعاد لاحقيه نفس قوله وكلامه. } \\
& \text { ثانياً: التوصيات: }
\end{aligned}
$$

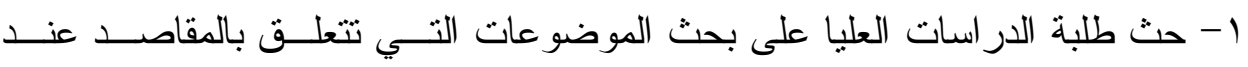

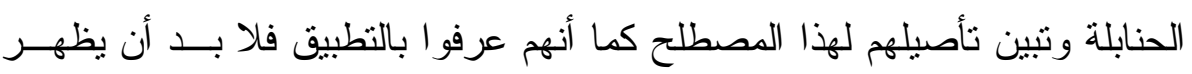
الجانب التأصيلي لديهم.

r- أوصي كذلك بالتوسط بالأخذ بالمقاصد و إنز الها منزلها كما كان بوصي ابن تيمية رحمه الله - بذلك. 


\section{المر اجع و المصادر}

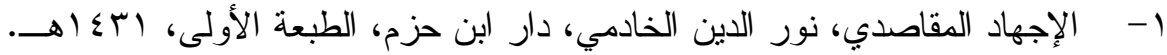

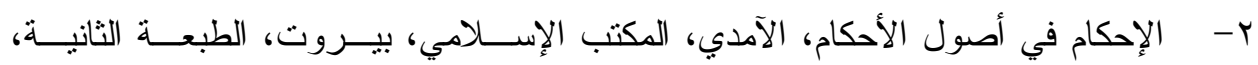
.

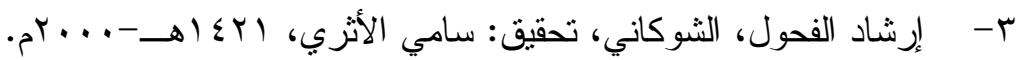

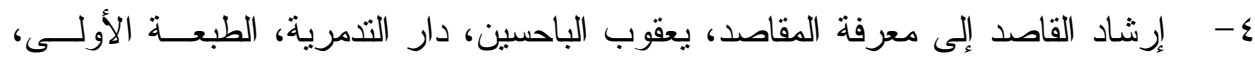
. $\rightarrow \leqslant \mu$

ه- أصول الجصاص [الفصول في الأصول]، الجصاص، وزارة الكويت، الطبعة الثانيــة، . م) $99 \varepsilon-\rightarrow \mid \leq 1 \leq$

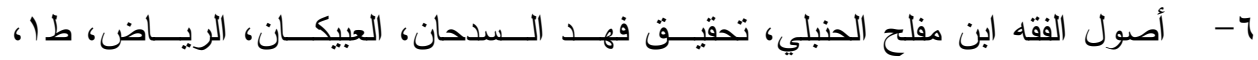
. $9999-\rightarrow 1 \leqslant r$. V- - أصول مذهب أحمد عبد المحسن الثركي، مؤسسة الرسالة، بيروت، الطبعــة الر ابعــة، . $1997-ه 1517$

^- - البحر المحيط في أصول الفقه، الزركثي، تحقيق: عبد القــادر، دار الكتـب، الطبعــة

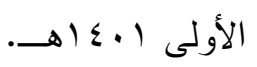

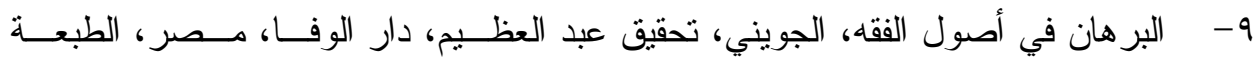

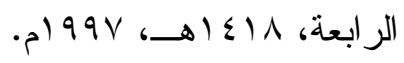

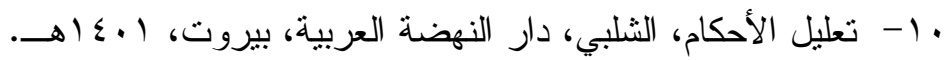

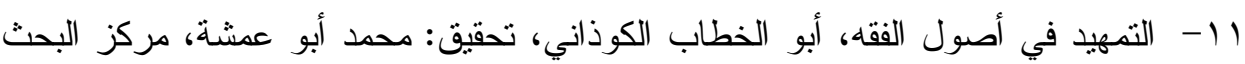

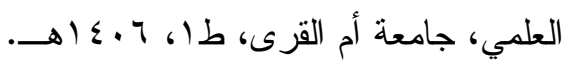

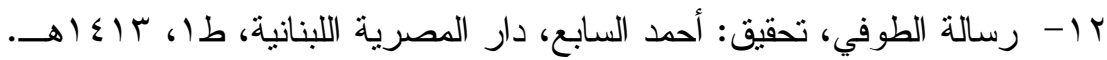
rا $\cdot{ }^{2}+\cdot r$

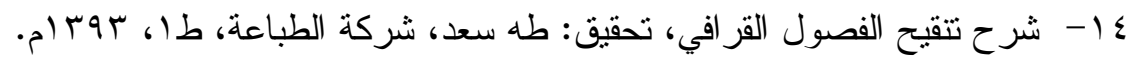

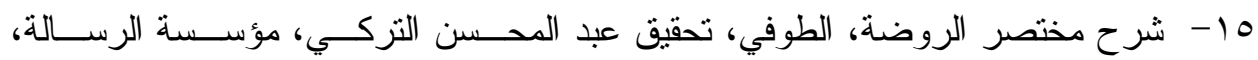

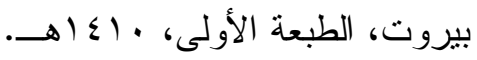
17 - شفاء الغليل، الغز الي، تحقيق: حمد الكبيسي، مطبعة الإرشاد، بغداد، . 9 ب اهـــ. 
V IV - الطرق الحكمية، ابن القيم، تحقيق: محمد غازي، مطبعة المدني، القاهرة.

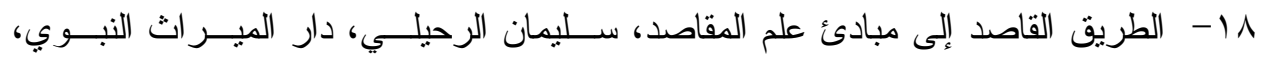
. إله

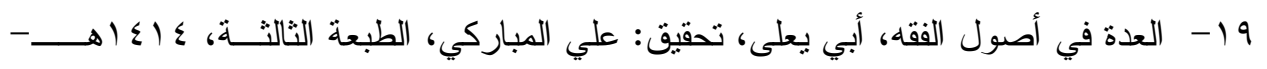
. 994

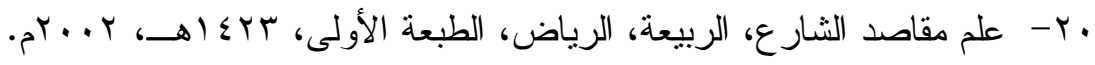

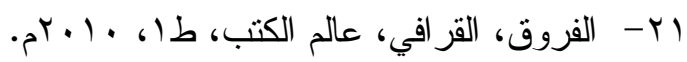

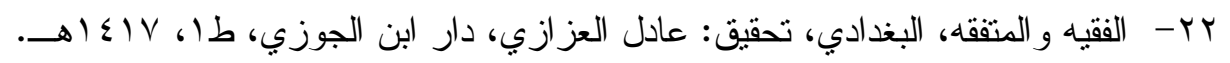

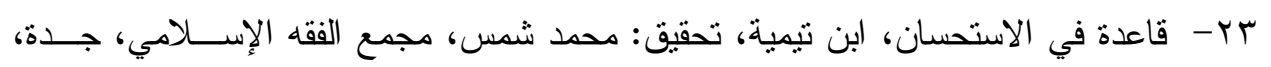
. $\rightarrow$ I

ع ז- قو اعد الأحكام في مصارح الأنام، العز بن عبد السلام، تحقيق: الحكمي، مكتبة الكليـات

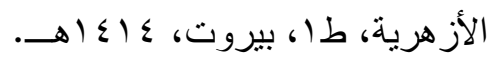

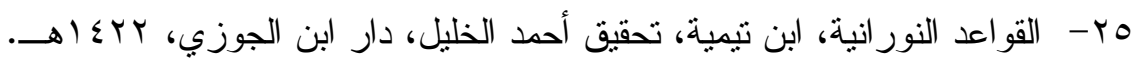

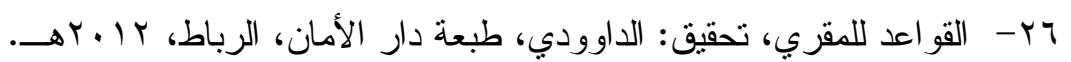
VY بيروت.

^ץ - كثف الأسرار في شرح أصول البزدوي عبد العزيز الحنفي، دار الكتاب الإسلامي.

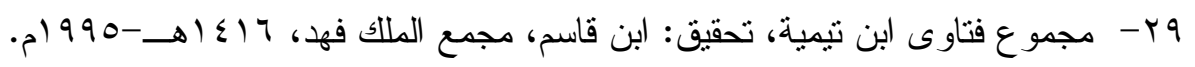
•r- مختصر التحرير شرح الكوكب المنير، الفتوحي، تحقيق: محمد زحيلي، مكتبة العبيكان،

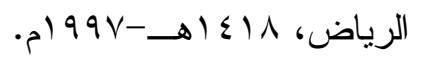

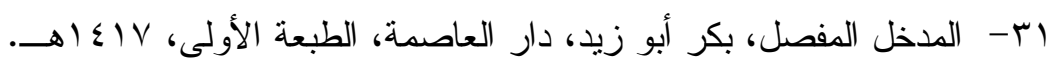

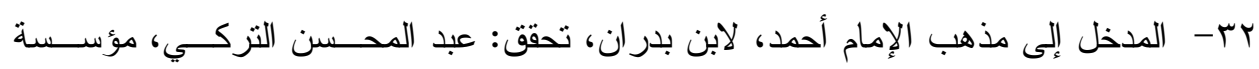

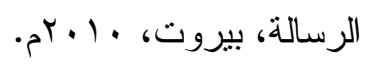

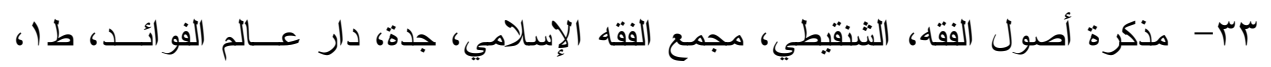
. I EY

ع ب- المستصفى، للغز الي، دار العلوم الحديثة، بيروت. 
هـ- المسودة، أبو البركات، أبو المحاسن، وشيخ الإسلام ابن تيمية، تحقيق: محمــد محيـي لئي الدين، دار الكتاب العربي، بيروت، لبنان.

צr- مقاصد الثريعة الإسلامية، سعد اليوبي، دار ابن الجوزي، الطبعة السادسة، بــأهـ.

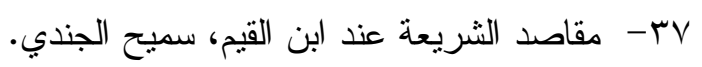

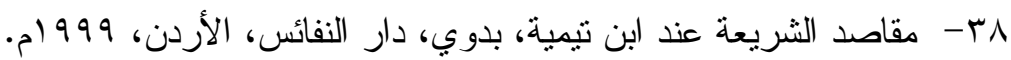

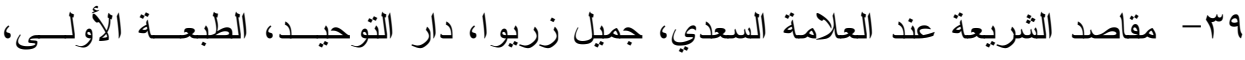

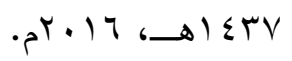

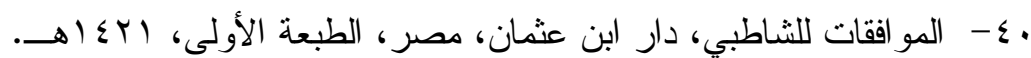

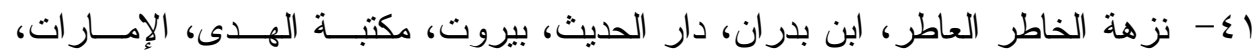
.01991 
